Article

\title{
Silicon Fertigation Regimes Attenuates Cadmium Toxicity and Phytoremediation Potential in Two Maize (Zea mays L.) Cultivars by Minimizing Its Uptake and Oxidative Stress
}

\author{
Muhammad Hamzah Saleem ${ }^{1} \mathbb{D}$, Abida Parveen ${ }^{2, *}$, Shahid Ullah Khan ${ }^{1,3}$ (D) Iqbal Hussain ${ }^{2}$, Xiukang Wang ${ }^{4}$, \\ Huda Alshaya ${ }^{5}$, Mohamed A. El-Sheikh ${ }^{6}$ (D) and Shafaqat Ali ${ }^{7,8, *(\mathbb{D})}$
}

Citation: Saleem, M.H.; Parveen, A.; Khan, S.U.; Hussain, I.; Wang, X.;

Alshaya, H.; El-Sheikh, M.A.; Ali, S. Silicon Fertigation Regimes Attenuates Cadmium Toxicity and Phytoremediation Potential in Two Maize (Zea mays L.) Cultivars by Minimizing Its Uptake and Oxidative Stress. Sustainability 2022, 14, 1462. https://doi.org/10.3390/su14031462

Academic Editor: José Manuel Mirás-Avalos

Received: 22 December 2021

Accepted: 22 January 2022

Published: 27 January 2022

Publisher's Note: MDPI stays neutral with regard to jurisdictional claims in published maps and institutional affiliations.

Copyright: (c) 2022 by the authors. Licensee MDPI, Basel, Switzerland. This article is an open access article distributed under the terms and conditions of the Creative Commons Attribution (CC BY) license (https:// creativecommons.org/licenses/by/ $4.0 /)$.
1 College of Plant Sciences and Technology, Huazhong Agricultural University, Wuhan 430070, China; saleemhamza312@webmail.hzau.edu.cn (M.H.S.); shahidbiochem@webmail.hzau.edu.cn (S.U.K.)

2 Department of Botany, Government College University, Faisalabad 38000, Pakistan; driqbal@gcuf.edu.pk

3 Department of Biochemistry, Women Medical and Dental College, Abbottabad 22080, Pakistan

4 College of Life Sciences, Yan'an University, Yan'an 716000, China; wangxiukang@yau.edu.cn

5 Cell and Molecular Biology, University of Arkansas, Fayetteville, NC 72701, USA; hmalshay@uark.edu

6 Botany \& Microbiology Department, College of Science, King Saud University, P.O. Box 2455,

Riyadh 11452, Saudi Arabia; melsheikh@ksu.edu.sa

7 Department of Environmental Sciences and Engineering, Government College University, Allama Iqbal Road, Faisalabad 38000, Pakistan

8 Department of Biological Sciences and Technology, China Medical University, Taichung City 40402, Taiwan

* Correspondence: drabida@gcuf.edu.pk (A.P.); shafaqataligill@yahoo.com (S.A.)

\begin{abstract}
Silicon (Si) is an important plant-derived metabolite that is significantly involved in maintaining the stability of a plant's metabiological, structural and physiological characteristics under the abiotic stressed environment. We conducted the present study using maize (Zea mays L.) cultivars (Sadaf and EV-20) grown in sand artificially contaminated with cadmium (500 $\mu \mathrm{M})$ in Hoagland's nutrient solution to investigate its efficiency. Results from the present study evidenced that the toxic concentration of $\mathrm{Cd}$ in sand significantly reduced shoot length, root length, shoot fresh weight, root fresh weight, shoot dry weight and root dry weight by 88, 94, 89, 8699 and 99\%, respectively, in Sadaf while decreasing by 98, 97, 93, 99, 84 and 91\%, respectively, in EV-20. Similarly, $\mathrm{Cd}$ toxicity decreased total chlorophyll and carotenoid content in both varieties of Z. mays. Moreover, the activities of various antioxidants (superoxidase dismutase, peroxidase and catalase) increased under the toxic concentration of $\mathrm{Cd}$ in sand which was manifested by the presence of membrane permeability, malondialdehyde (MDA), and hydrogen peroxide $\left(\mathrm{H}_{2} \mathrm{O}_{2}\right)$. Results additionally showed that the toxic effect of $\mathrm{Cd}$ was more severe in EV-20 compared with Sadaf under the same conditions of environmental stresses. In addition, the increased concentration of $\mathrm{Cd}$ in sand induced a significantly increased Cd accumulation in the roots (141 and $169 \mathrm{mg} \mathrm{kg}^{-1}$ in Sadaf and EV-20, respectively), and shoots (101 and $141 \mathrm{mg} \mathrm{kg}^{-1}$ in Sadaf and EV-20, respectively), while; EV-20 accumulated higher amounts of $\mathrm{Cd}$ than Sadaf, with the values for both bioaccumulation factor (BAF) and translocation factor (TF) among all treatments being less than 1 . The subsequent negative results of Cd injury can be overcome by the foliar application of $\mathrm{Si}$ which not only increased plant growth and biomass, but also decreased oxidative damage induced by the higher concentrations of MDA and $\mathrm{H}_{2} \mathrm{O}_{2}$ under a $\mathrm{Cd}$-stressed environment. Moreover, external application of $\mathrm{Si}$ decreased the concentration of $\mathrm{Cd}$ in the roots and shoots of plants, therefore suggesting that the application of Si can ameliorate $\mathrm{Cd}$ toxicity in Z. mays cultivars and results in improved plant growth and composition under Cd stress by minimizing oxidative damage to membrane-bound organelles.
\end{abstract}

Keywords: oxidative stress; antioxidants defense system; cadmium stress; silicon; chlorophyll pigments; cereal crops 


\section{Introduction}

Metal contamination issues are becoming increasingly common across the world, with many documented cases of metal toxicity in mining industries, foundries, smelters, coal-burning power plants and agriculture [1,2]. Among various toxic pollutants, Cadmium $(\mathrm{Cd})$ is a more prominent toxic pollutant due to its severe toxicity and ability to induce damage to normal growth and development [3,4]. Cd, a known toxic heavy metal, possesses properties of water solubility, phytotoxicity, higher rates of relative mobility, and can induce toxicity to membrane-bound organelles $[5,6]$. Moreover, $\mathrm{Cd}$ is classified as a non-essential element for plant growth and development and its high accumulation in the plant organs is particularly concerning [7]. Plants absorb Cd through active transport of Fe transporters and by passive transport through ionic transcription rates by transferring through xylem and phloem transportation processes [8,9]. Hence, accumulation of $\mathrm{Cd}$ leads to the deficiency of iron, calcium, and magnesium by disturbing morphological and biochemical processes in plants [10]. Furthermore, Cd-toxicity damages plant cells including chloroplasts, cell nuclei, and mitochondria leading to a reduction in chlorophyll [11]. Due to increased Cd-stress, the formation of reactive oxygen species (ROS) arises that do not partake in Fenton-type reactions, which ultimately initiates destructive pathways in plants [12]. The peroxidation of lipids significantly enhances the accumulation of malondialdehyde (MDA) content [13,14]. The generation of ROS are easily handled by plants through adopting extremely effective endogenous approaches for the mitigation of ROS by implementing enzymatic and non-enzymatic antioxidants of their constituents $[15,16]$. The principal antioxidant enzymes are catalase (CAT), ascorbate peroxide (APX), and superoxide dismutase (SOD) which were characterized by converter hydrogen peroxide $\left(\mathrm{H}_{2} \mathrm{O}_{2}\right)$, and superoxide $\left(\mathrm{O}^{-2}\right)$ to mitigate toxicity in plants and reduce the concentration of MDA and $\mathrm{H}_{2} \mathrm{O}_{2}$ [17-19]. Therefore, it remains a priority to decrease the concentration of $\mathrm{Cd}$ in nutritional crops to limit transmission into the food chain [20].

Silicon (Si) is the second most abundant metalloid found in the form of mono-silicic acid and is an essential chemical element in plant biology (required by plants, animals and microorganisms) $[5,11]$. It is a beneficial element for plants and improves the structural integrity of plants exposed to conditions of environmental stress, most importantly; salt, heavy metals, drought, temperature changes and freezing, pests and disease stresses [21]. From soil, uptake of $\mathrm{Si}$ depends on the type of growth medium, soil properties and plant species where plants are classified as high-, medium- and low-Si accumulators [22]. A number of studies revealed that $\mathrm{Si}$ application increased plant growth and biomass [23], mineral uptake [24], gaseous exchange attributes [25], and reduced oxidative stress by scavenging reactive oxygen species (ROS) [26], and diminished accumulation of organic acids in different plant species [11]. Moreover, maize (Zea mays L.) also known as corn, is the main cereal grain crop that is cultivated worldwide [27]. As (Zea mays L.) remains an important food crop, it is known to be a social security concern for farmers [27] and an important feed and industrial source [28]. In previous studies, Z. mays was used widely to cultivate under $C d$-stressed environments as an efficient source of phytoextraction and plants were able to accumulate $\mathrm{Cd}$ contents in their roots and shoots [29]. According to previous studies, the loss in the yield of $Z$. mays mainly depended upon the accumulation of heavy metals (especially Cd) in the soil [30]. Hence, it is extremely important to find possible methods which can ameliorate $\mathrm{Cd}$ toxicity in $\mathrm{Z}$. mays to able to fulfil the market demands of this cereal crop. Therefore, there remains an increasing demand for $\mathrm{Cd}$ minimization in Z. mays for the agro-environmental sustainability of world maize production and food safety.

Over the recent years, various applications such as crop residues, manure, compost, fertilizers, micronutrients, and biochar are being commonly used, and certain heavy metals have received considerable attention regarding plant morphology and physiology owing to increasing environmental exposure, which are additionally likely to bear negative impacts on cereal crops including Z. mays. Previously, numerous studies were conducted using $Z$. mays under the toxic environment of $\mathrm{Cd}$ stress, however, the foliar application of $\mathrm{Si}$ on various growth and physiological attributes of $Z$. mays was rarely investigated under 
metal stressed conditions. Therefore, the present research was conducted to investigate (I) the effect of $\mathrm{Si}$ application on the growth and biomass (II) photosynthetic pigments (III) antioxidant capacity and (IV) phytoremediation potential of Z. mays under toxic levels of $\mathrm{Cd}$ in sand. Hence, results from the present study will help improve the understanding behind the mechanism of plant tolerance and mobilization of $\mathrm{Cd}$ concentration among the various parts of plants using foliar applications of $\mathrm{Si}$.

\section{Materials and Methods}

The mature and healthy seeds of maize (Z. mays) cultivars (Sadaf and EV-20) were collected from the Ayub Agricultural Research Institute (AARI), Faisalabad 38000, Pakistan. A pot experiment was conducted in the greenhouse of the Department of Botany, Government College University, Faisalabad 38000, Punjab, Pakistan ( $\left.31^{\circ} 24 / \mathrm{N}, 73^{\circ} 04 / \mathrm{E}\right)$. Before seed sowing, the seeds were carefully washed and sterilized in $0.1 \% \mathrm{HgCl}_{2}$ solution for $1 \mathrm{~min}$ and then washed thrice with distilled water. All pots $(35 \mathrm{~cm}$ height $\times 25 \mathrm{~cm}$ width) were covered with plastic bags. For the complete removal of cations and anions, the sand was washed with distilled water several times. After that, in each pot, about 15 seeds were sown and each pot was kept in a greenhouse where they received natural light and air. Each pot was placed in a randomized manner with three replicates per treatment being carried out. The overall average day/night temperature was $19 \pm 3 / 10 \pm 2{ }^{\circ} \mathrm{C}$, with a relative humidity of $62.0-65.1 \%$, and the day length averaged $10-11$ hours per day, respectively. For the onset of any emergency, $\frac{1}{2}$ strength Hoagland's solution was prepared [31] and poured in each pot at an interval of every 5 days. The $\mathrm{pH}$ of soil was adjusted to values ranging from 6.0-6.2 using diluted $\mathrm{H}_{2} \mathrm{SO}_{4}$ solution. After one week, the propagated $\mathrm{Z}$. mays seedlings were treated by inducing $\mathrm{Cd}$ stress. For the application of $\mathrm{Cd}$ stress, cadmium chloride $\left(\mathrm{CdCl}_{2}\right)$ salt was used. The concentration of $\mathrm{Cd}(500 \mu \mathrm{M})$ was added to the Hoagland's media. For the comparison group, the seedlings without $C d$ stress were treated as a control $(\mathrm{Cd} 0 \mu \mathrm{M})$. Meanwhile, the set of treatments were arranged as $\mathrm{Si}(6 \mathrm{mM})$ applied for foliar application, $\mathrm{Cd}(500 \mu \mathrm{M})$ for soil, and $\mathrm{Si} \times \mathrm{Cd}(6 \mathrm{mM}$ and $500 \mu \mathrm{M})$ were applied, respectively. $\mathrm{K}_{2} \mathrm{SiO}_{3}$ salt $(6 \mathrm{mM})$ with Twin-20 reagent was sprayed. After three weeks of stress treatment, the data were recorded for various biochemical and growth parameters, respectively.

\subsection{Parameters}

\subsubsection{Growth Attributes}

Experimental data were collected from the propagated shoot and root lengths, as well as the weight of fresh and dry leaves of the two cultivars, which were recorded. Root length and shoot length was measured using a measuring scale from the tips of the shoots to the bottom of the root tips. After that, fresh biomass (roots and shoots) was also measured using a weighting digital balance by selecting three randomly plants per treatment. The plant samples were oven-dehydrated at $65^{\circ} \mathrm{C}$ for $72 \mathrm{~h}$ for $\mathrm{Cd}$ and ions concentration determination and the total plant dry weight was also measured. Before being oven-dried, roots were immersed in $20 \mathrm{mM} \mathrm{Na} 2$ EDTA for 15-20 min to remove $\mathrm{Cd}$ that had adhered to the surface of roots. Subsequently, roots were washed thrice with distilled water and finally once with deionized water then dried for further analysis.

\subsubsection{Photosynthetic Pigments}

Leaves were collected for the determination of chlorophyll and carotenoid contents. For chlorophyll, $0.1 \mathrm{~g}$ of fresh leaf sample was extracted using $8 \mathrm{~mL}$ of $95 \%$ acetone for $24 \mathrm{~h}$ at $4{ }^{\circ} \mathrm{C}$ under dark conditions. The absorbance was measured by a spectrophotometer (UV-2550; Shimadzu, Kyoto, Japan) at 646.6, 663.6, and $450 \mathrm{~nm}$. Chlorophyll content was calculated using the standard method of Arnon [32].

\subsubsection{Measurement of $\mathrm{H}_{2} \mathrm{O}_{2}$ Contents}

To estimate $\mathrm{H}_{2} \mathrm{O}_{2}$ content of plant tissues (root and leaf), $3 \mathrm{~mL}$ of sample extract was mixed with $1 \mathrm{~mL}$ of $0.1 \%$ titanium sulfate in $20 \%(v / v) \mathrm{H}_{2} \mathrm{SO}_{4}$ and centrifuged at $6000 \times g$ 
for $15 \mathrm{~min}$. The yellow color intensity was evaluated at $410 \mathrm{~nm}$. The $\mathrm{H}_{2} \mathrm{O}_{2}$ level was computed by the extinction coefficient of $0.28 \mathrm{mmol}^{-1} \mathrm{~cm}^{-1}$. The contents of $\mathrm{H}_{2} \mathrm{O}_{2}$ were measured by the method presented by Jana and Choudhuri [33].

\subsubsection{Malondialdehyde (MDA) Contents}

The degree of lipid peroxidation was evaluated as malondialdehyde (MDA) contents. Briefly, $0.1 \mathrm{~g}$ of frozen leaves were ground at $4{ }^{\circ} \mathrm{C}$ in a mortar with $25 \mathrm{~mL}$ of $50 \mathrm{mM}$ phosphate buffer solution ( $\mathrm{pH} 7.8$ ) containing $1 \%$ polyethene pyrrole. The homogenate was centrifuged at $10,000 \times g$ at $4{ }^{\circ} \mathrm{C}$ for $15 \mathrm{~min}$. The mixtures were heated at $100{ }^{\circ} \mathrm{C}$ for 15-30 min and then quickly cooled in an ice bath. The absorbance of the supernatant was recorded by using a spectrophotometer (xMark ${ }^{\mathrm{TM}}$ Microplate Absorbance Spectrophotometer; Bio-Rad, Hercules, CA, USA) at wavelengths of 532, 600, and $450 \mathrm{~nm}$. Lipid peroxidation was expressed as $1 \mathrm{~mol} \mathrm{~g}^{-1}$ by using the formula: 6.45 (A532 - A600) - 0.56 A450. Lipid peroxidation was measured using a method previously published by Heath and Packer [34].

\subsubsection{Relative Membrane Permeability (RMP)}

Fresh leaves from $Z$. mays seedlings $(0.5 \mathrm{~g})$ were cut into uniformly sized pieces and placed in a test tube with $10 \mathrm{ml}$ deionized water. Test tubes were incubated at $25{ }^{\circ} \mathrm{C}$ for $2 \mathrm{~h}$ and $\mathrm{EC}$ was measured. Then, the test tubes were left overnight and $\mathrm{EC}_{1}$ was measured. Afterward, the test tubes were autoclaved at $1000{ }^{\circ} \mathrm{C}$ for $1 \mathrm{~h}$ and $\mathrm{EC}_{2}$ was measured. The calculation was done with the help of the formula used by researchers in [35].

\subsubsection{Antioxidant Activities Determination}

To evaluate enzyme activities, fresh leaves $(0.5 \mathrm{~g})$ were homogenized in liquid nitrogen and $5 \mathrm{~mL}$ of $50 \mathrm{mmol}$ sodium phosphate buffer ( $\mathrm{pH} 7.0$ ), including $0.5 \mathrm{mmol}$ EDTA and $0.15 \mathrm{~mol} \mathrm{NaCl}$. The homogenate was centrifuged at $12,000 \times g$ for $10 \mathrm{~min}$ at $4{ }^{\circ} \mathrm{C}$, and the supernatant was used for measurement of superoxidase dismutase (SOD) and peroxidase (POD) activities. SOD activity was assayed in a $3 \mathrm{~mL}$ reaction mixture containing $50 \mathrm{mM}$ sodium phosphate buffer ( $\mathrm{pH}$ 7), $56 \mathrm{mM}$ nitro blue tetrazolium, $1.17 \mathrm{mM}$ riboflavin, $10 \mathrm{mM}$ methionine, and $100 \mu \mathrm{L}$ enzyme extract. Finally, the sample was measured using a spectrophotometer (xMark ${ }^{\mathrm{TM}}$ Microplate Absorbance Spectrophotometer; Bio-Rad). Enzyme activity was measured by using a method employed by Chen and Pan [36] and expressed as $\mathrm{U} \mathrm{g}^{-1}$ FW. POD activity in the leaves was estimated by using the method of Sakharov and Ardila [37] employed by using guaiacol as the substrate. A reaction mixture ( $3 \mathrm{~mL})$ containing $0.05 \mathrm{~mL}$ of enzyme extract, $2.75 \mathrm{~mL}$ of $50 \mathrm{mM}$ phosphate buffer $(\mathrm{pH} 7.0), 0.1 \mathrm{~mL}$ of $1 \% \mathrm{H}_{2} \mathrm{O}_{2}$, and $0.1 \mathrm{~mL}$ of $4 \%$ guaiacol solution was prepared. Increases in the absorbance at $470 \mathrm{~nm}$ due to guaiacol oxidation was recorded for $2 \mathrm{~min}$. One unit of enzyme activity was defined as the amount of the enzyme. Catalase (CAT) activity was analyzed according to Aebi [38]. The assay mixture $(3.0 \mathrm{~mL})$ was comprised of $100 \mu \mathrm{L}$ enzyme extract, $100 \mu \mathrm{L}$ $\mathrm{H}_{2} \mathrm{O}_{2}(300 \mathrm{mM})$, and $2.8 \mathrm{~mL} 50 \mathrm{mM}$ phosphate buffer with $2 \mathrm{mM}$ ETDA (pH 7.0). The CAT activity was measured by the decline in absorbance at $240 \mathrm{~nm}$ as a result of $\mathrm{H}_{2} \mathrm{O}_{2}$ loss $\left(\varepsilon=39.4 \mathrm{mM}^{-1} \mathrm{~cm}^{-1}\right)$.

\subsubsection{Determination of $\mathrm{Cd}$}

The ground samples were digested with pure $\mathrm{HNO}_{3}$ at $190{ }^{\circ} \mathrm{C}$ for $45 \mathrm{~min}$ (10 min preheating, 15 min heating, 20 min cooling) in a microwave oven (Mars 6, CEM Corporation, Matthews, NC, USA) with the settings described in detail by Jezek et al., [39]. Samples were diluted with $2 \% \mathrm{HNO}_{3}$ and determined by an atomic absorption spectrophotometer (AAS), model Agilent 240FS-AA.

Bioaccumulation factor (BAF) was calculated as the ratio of $\mathrm{Cd}$ concentration in tissues and $\mathrm{Cd}$ concentration in nutrient media, by using the following formula:

$\mathrm{BAF}=\mathrm{Cd}$ concentration (plant tissues) $/ \mathrm{Cd}$ concentration (nutrient media) 
while the translocation factor (TF) was determined by estimating the concentration of $\mathrm{Cd}$ in one part of the plant with respect to the other parts as follows:

$$
\mathrm{TF}=\mathrm{Cd} \text { concentration (shoots) } / \mathrm{Cd} \text { concentration (roots) }
$$

\subsubsection{Statistical Analysis}

Statistical analysis of data were performed with analysis of variance (ANOVA) by using a statistical program Co-Stat version 6.2, Cohorts Software, 2003, Monterey, CA, USA. All the data obtained were tested by two-way analysis of variance (two-way ANOVA). Thus, the differences between treatments were determined by using ANOVA, and the least significant difference test $(p<0.05)$ was used for multiple comparisons between treatment means. Logarithmic or inverse transformations were performed for data normalization, where necessary, prior to analysis. Pearson's correlation analysis was performed to quantify relationships between various analyzed variables. The graphical presentation was carried out by using Origin-Pro 2017. The Pearson correlation coefficients and the principal component analysis between the measured variables of $Z$. mays were also calculated using RStudio software.

\section{Results}

3.1. Effect of Foliar Appliacation of Si on Plant Growth and Biomass in Both Varieties of Z. mays Grown under the Toxic Concentration of $\mathrm{Cd}$ in the Sand

In the present study, various growth and biomass parameters were also measured in both varieties of $Z$. mays (Sadaf and EV-20) grown under the application of $\mathrm{Si}(3 \mathrm{mM}$ ) with or without the toxic concentration of $C d(500 \mu \mathrm{M})$ in the sand. The data regarding root and shoot length, fresh and dry biomass in both varieties of $Z$. mays is presented in Figure 1. According to the results, it was noticed that the toxic amount of $\mathrm{Cd}(500 \mu \mathrm{M})$ in the sand significantly $(p<0.05)$ decreased root length, shoot length, root fresh weight, shoot fresh weight, root dry weight and shoot dry weight in both cultivars of Z. mays, compared with the plants grown in the control treatment $(0 \mu \mathrm{M} \mathrm{Cd}$ concentration) (Figure 1; Table 1). Compared with the control treatment, maximum decreases of 88, 94, 89, 86, 99 and $99 \%$ in root length, shoot length, root fresh weight, shoot fresh weight, root dry weight and shoot dry weight, respectively, were observed in Sadaf, while decreases of 98, 97, 93, 99, 84 and $91 \%$, respectively, in EV-20, were observed in the plants grown under the toxic concentration of $\mathrm{Cd}(500 \mu \mathrm{M})$ in the sand. Results also showed that the toxic effect of $\mathrm{Cd}$ was more severe in EV-20 compared with Sadaf under the same environmental stressed condition in terms of plant growth and biomass attributes. Although, plant growth and biomass of $Z$. mays cultivars under the toxic concentration of the $\mathrm{Cd}$ in the sand could be improved by the foliar application of $\mathrm{Si}$ (Figure 1; Table 1). The application of Si increased the root length, shoot length, root fresh weight, shoot fresh weight, root dry weight and shoot dry weight by $0.6,0.7,0.2,0.6,0.7$ and $0.6 \%$, respectively, in the Sadaf, and also increased by $1.2,0.5,0.1,0.7,0.4$ and $0.3 \%$, respectively, in the EV-20 plants grown under the application of $\mathrm{Si}(3 \mathrm{mM})$, compared with plants grown in sand without the application of Si $(0 \mathrm{mM})$.

\subsection{Effect of Foliar Appliacation of Si on Chlorophyll Pigments in Both Varieties of Z. mays Grown} under the Toxic Concentration of $\mathrm{Cd}$ in the Sand

We also demonstrated various photosynthetic pigments in both cultivars (Sadaf and EV-20) of Z. mays grown under the toxic concentration of Cd $(500 \mu \mathrm{M})$ in sand with or without the foliar application of Si (Figure 2; Table 2). Results showed that plants which were grown in the toxic amount of $\mathrm{Cd}$ in the sand significantly $(p<0.05)$ decreased chlorophyll a, chlorophyll $\mathrm{b}$, total chlorophyll and carotenoid content in both cultivars of $Z$. mays compared with the plants grown in the control treatment. However, the results also advocated that Sadaf showed a greater concentration of photosynthetic pigments compared with EV-20 under the same level of stress in the sand. The concentrations of chlorophyll and carotenoid could be enhanced in both cultivars of Z. mays by the foliar 
application of Si which increased these pigments significantly even in the Cd-contaminated sand. Our results showed that the application of Si increased chlorophyll a, chlorophyll b, total chlorophyll and carotenoid contents by $0.026,0.034,0.31$ and $0.06 \%$, respectively, in Sadaf while also increasing by $0.03,0.046,0.42$ and $0.08 \%$, respectively, in EV-20 in the plants which were grown in sand containing the toxic concentration of $\mathrm{Cd}$ upon foliar application of $\mathrm{Si}(3 \mathrm{mM})$ compared with plants which were grown without the foliar application of $\mathrm{Si}$.
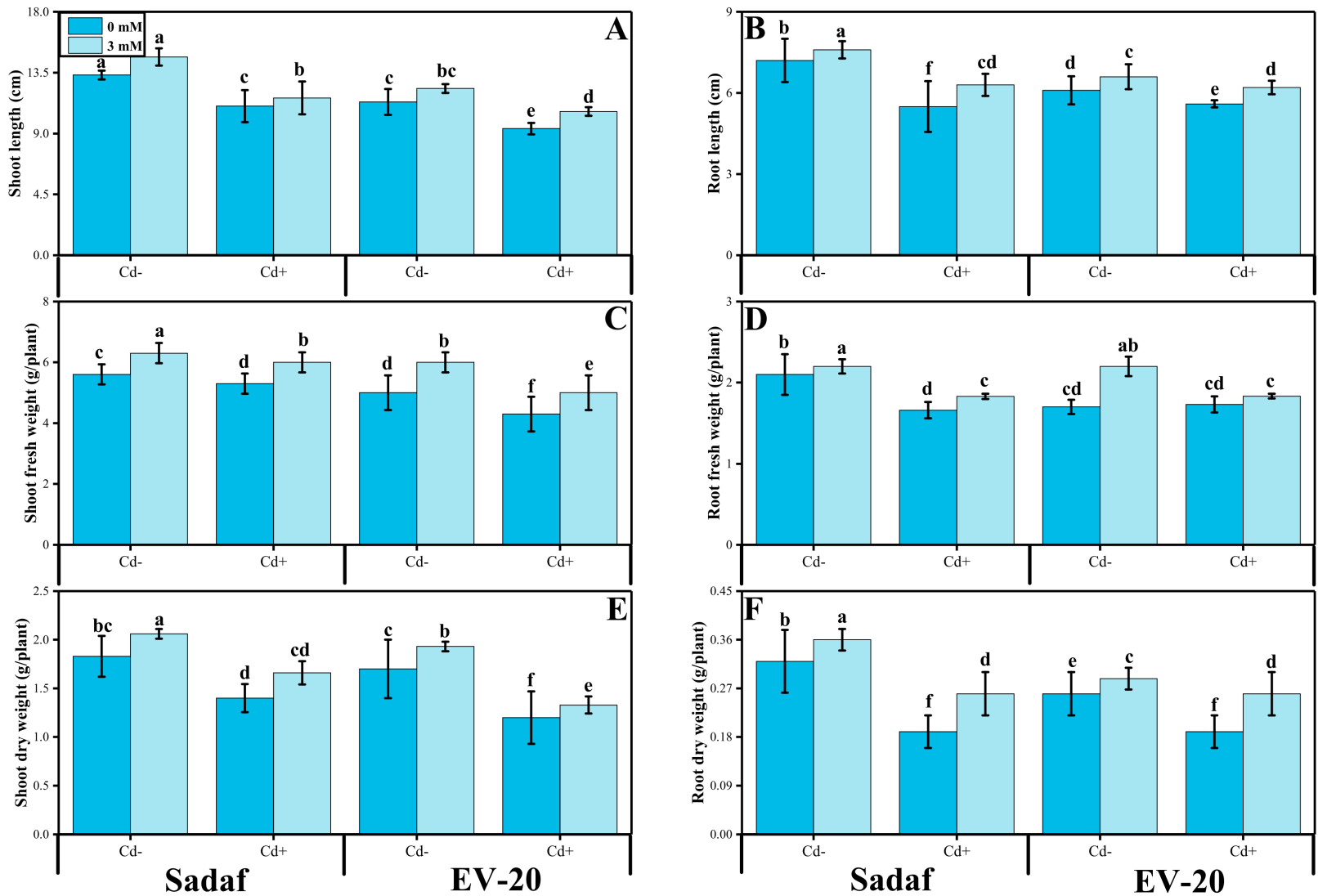

Figure 1. Effect of different levels of Si $(0$ and $6 \mathrm{mM})$ on shoot length (A), root length (B), shoot fresh weight (C), root fresh weight (D), shoot dry weight (E) and root dry weight (F) under the toxic concentration of $\mathrm{Cd}(500 \mu \mathrm{M})$ in the sand in both cultivars of Z. mays (Sadaf and EV-20). All the data represented were the average of three replications $(n=3)$. Error bars represent the standard deviation (SD) of three replicates. Different lowercase letters on the error bars indicate a significant difference between the treatments.

Table 1. Mean square values from ANOVA of data for foliar applied silicon modulate growth in Z. mays cultivars grown under cadmium stress conditions.

\begin{tabular}{llllllll}
\hline Source of Variance & df & Shoot Length & Root Length & $\begin{array}{l}\text { Shoot Fresh } \\
\text { Weight }\end{array}$ & $\begin{array}{l}\text { Shoot Dry } \\
\text { Weight }\end{array}$ & $\begin{array}{l}\text { Root Fresh } \\
\text { Weight }\end{array}$ & $\begin{array}{l}\text { Root Dry } \\
\text { Weight }\end{array}$ \\
\hline Varieties (V) & 1 & $18.47^{* * *}$ & $420.74^{* * *}$ & $661.54^{* * *}$ & $92.0^{* *}$ & $0.02 \mathrm{~ns}$ & $0.082 \mathrm{~ns}$ \\
Cd stress (S) & 1 & $166.05^{* * *}$ & $1858.70^{* * *}$ & $18.64^{* *}$ & $80.05^{* * *}$ & $31.15^{* * *}$ & $2.38^{* * *}$ \\
Treatments (T) & 1 & $67.04^{* * *}$ & $355.80^{* * *}$ & $160.17^{* * *}$ & $35.04^{* * *}$ & $0.95^{* * *}$ & $0.449^{* * *}$ \\
$\mathrm{~V} \times \mathrm{S}$ & 1 & $4^{* * 04^{* *}}$ & $47.35^{* * *}$ & $25.16^{* * *}$ & $27.04^{* * *}$ & $0.05 \mathrm{~ns}$ & $0.16^{*}$ \\
$\mathrm{~V} \times \mathrm{T}$ & 1 & $6.04^{* * *}$ & $21.05^{* * *}$ & $27.16^{* * *}$ & $23.37^{* * *}$ & $0.01 \mathrm{~ns}$ & $0.01 \mathrm{~ns}$ \\
$\mathrm{~S} \times \mathrm{T}$ & 1 & $1.04 \mathrm{~ns}$ & $14.88^{* * *}$ & $28.16 \mathrm{~ns}$ & $16.04^{* *}$ & $0.042 \mathrm{~ns}$ & $0.071 \mathrm{~ns}$ \\
$\mathrm{~V} \times \mathrm{S} \times \mathrm{T}$ & 1 & $2.03 \mathrm{~ns}$ & $0.04^{* * *}$ & 1.15 & $3.03^{*}$ & $0.060 \mathrm{~ns}$ & $0.02 \mathrm{~ns}$ \\
Error & 16 & 3.45 & 0.70 & 1.25 & 3.83 & 0.032 & 0.026 \\
\hline
\end{tabular}

$*, * *, * * *=$ significant at $0.05,0.01$ and 0.001 levels, respectively. $\mathrm{ns}=$ non-significant. Abbreviations: $\mathrm{SL}=$ shoot length; RL = Root length; SFW = Shoot fresh weight; RFW = Root fresh weight; SDW = shoot dry weight; $\mathrm{RDW}=$ root dry weight. 

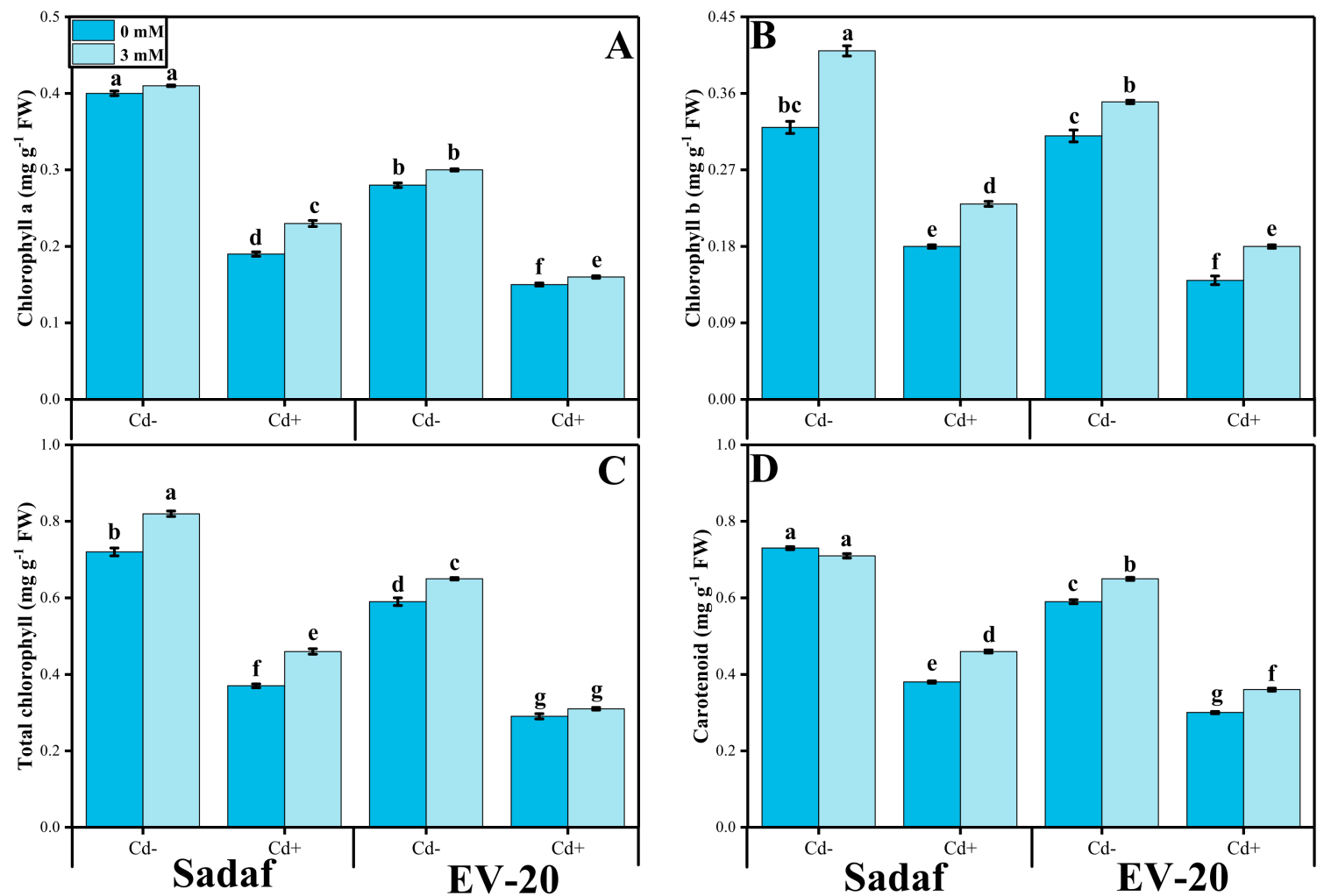

Figure 2. Effect of different levels of Si $(0$ and $6 \mathrm{mM})$ on chlorophyll a (A), chlorophyll b (B), total chlorophyll (C) and carotenoid (D) contents under the toxic concentration of Cd $(500 \mu \mathrm{M})$ in the sand in both cultivars of Z. mays (Sadaf and EV-20). All the data represented are the average of three replications $(n=3)$. Error bars represent the standard deviation $(S D)$ of three replicates. Different lowercase letters on the error bars indicate a significant difference between the treatments.

Table 2. Mean square values from ANOVA of data for foliar applied silicon modulate photosynthetic pigments in Z. mays cultivars grown under cadmium stress conditions.

\begin{tabular}{llllll}
\hline Source of Variance & df & Chl. a & Chl. b & Carotenoids & Total Chl. \\
\hline Varieties (V) & 1 & $4.77^{* *}$ & $31.04^{* *}$ & $0.145^{* * *}$ & $0.03 \mathrm{~ns}$ \\
Cd stress (S) & 1 & $4.60^{* * *}$ & $42.56^{* * *}$ & $0.314^{* * *}$ & $0.34 \mathrm{~ns}$ \\
Treatments (T) & 1 & $3.456^{* *}$ & $91.49^{* *}$ & $0.404^{* *}$ & $15.37^{* *}$ \\
$\mathrm{~V} \times \mathrm{S}$ & 1 & $5.16^{\mathrm{ns}}$ & $9.25 \mathrm{~ns}$ & $0.081^{*}$ & $0.03 \mathrm{~ns}$ \\
$\mathrm{~V} \times \mathrm{T}$ & 1 & $6.08^{* *}$ & $8.85^{* *}$ & $0.07 \mathrm{~ns}$ & $0.04 \mathrm{~ns}$ \\
$\mathrm{~S} \times \mathrm{T}$ & 1 & $4.132^{* *}$ & $9.54^{* *}$ & $0.02 \mathrm{~ns}$ & $0.04^{* *}$ \\
$\mathrm{~V} \times \mathrm{S} \times \mathrm{T}$ & 1 & 0.14 & 6.023 & $0.17 \mathrm{~ns}$ & $1.0 \mathrm{~ns}$ \\
Error & 16 & 0.354 & 0.13 & 0.09 & 3.46 \\
\hline
\end{tabular}

$*^{* *}, * * *=$ significant at $0.05,0.01$ and 0.001 levels, respectively. ns $=$ non-significant. Abbreviations: Chl. $\mathrm{a}=$ chlorophyll $\mathrm{a}, \mathrm{Chl} . \mathrm{b}=$ chlorophyll $\mathrm{b}$; Car. Carotenoids; Total. Chl. = Total chlorophyll.

\subsection{Effect of Foliar Appliacation of Si on Oxidative Stress Biomarkers, Relative Membrane Permeability and Antioxidant Capacity in Both Varieties of Z. mays Grown under the Toxic Concentration of $C d$ in the Sand}

Moreover, we measured various oxidative stress biomarkers such as malondialdehyde (MDA) and hydrogen peroxide $\left(\mathrm{H}_{2} \mathrm{O}_{2}\right)$ contents and relative membrane permeability (RMP) in $Z$. mays cultivars under the toxic concentration of the $\mathrm{Cd}$ in sand with or without the foliar application of Si (Figure 3; Table 1). Results showed that the toxic concentration of $\mathrm{Cd}$ in the sand significantly $(p<0.05)$ increased the contents of MDA, $\mathrm{H}_{2} \mathrm{O}_{2}$ and RMP in both cultivars of $Z$. mays, compared with the plants which were grown in normal sand (Figure 3; Table 1). Similarly, result showed that the activities of various antioxidants such as superoxide dismutase (SOD), peroxidase (POD) and catalase (CAT) were also 
increased in the plants which were grown in sand with the toxic concentration of $\mathrm{Cd}$ $(500 \mu \mathrm{M})$, compared with the plants which were grown in the Cd free sand (Figure 3; Table 1). However, the concentrations of MDA, $\mathrm{H}_{2} \mathrm{O}_{2}$ and RMP were higher in the Sadaf while the activities of antioxidants were higher in the EV-20. We also provided evidence that the application of Si significantly $(p<0.05)$ decreased the contents of MDA, $\mathrm{H}_{2} \mathrm{O}_{2}$ and RMP in both cultivars of Z. mays, compared with the plants which were not treated with $\mathrm{Si}$. In contrast, results additionally illustrated that the application of $\mathrm{Si}$ further increased the activities of various antioxidants (SOD, POD and CAT) in both cultivars of Z. mays, compared with the plants which were not treated with $\mathrm{Si}$.
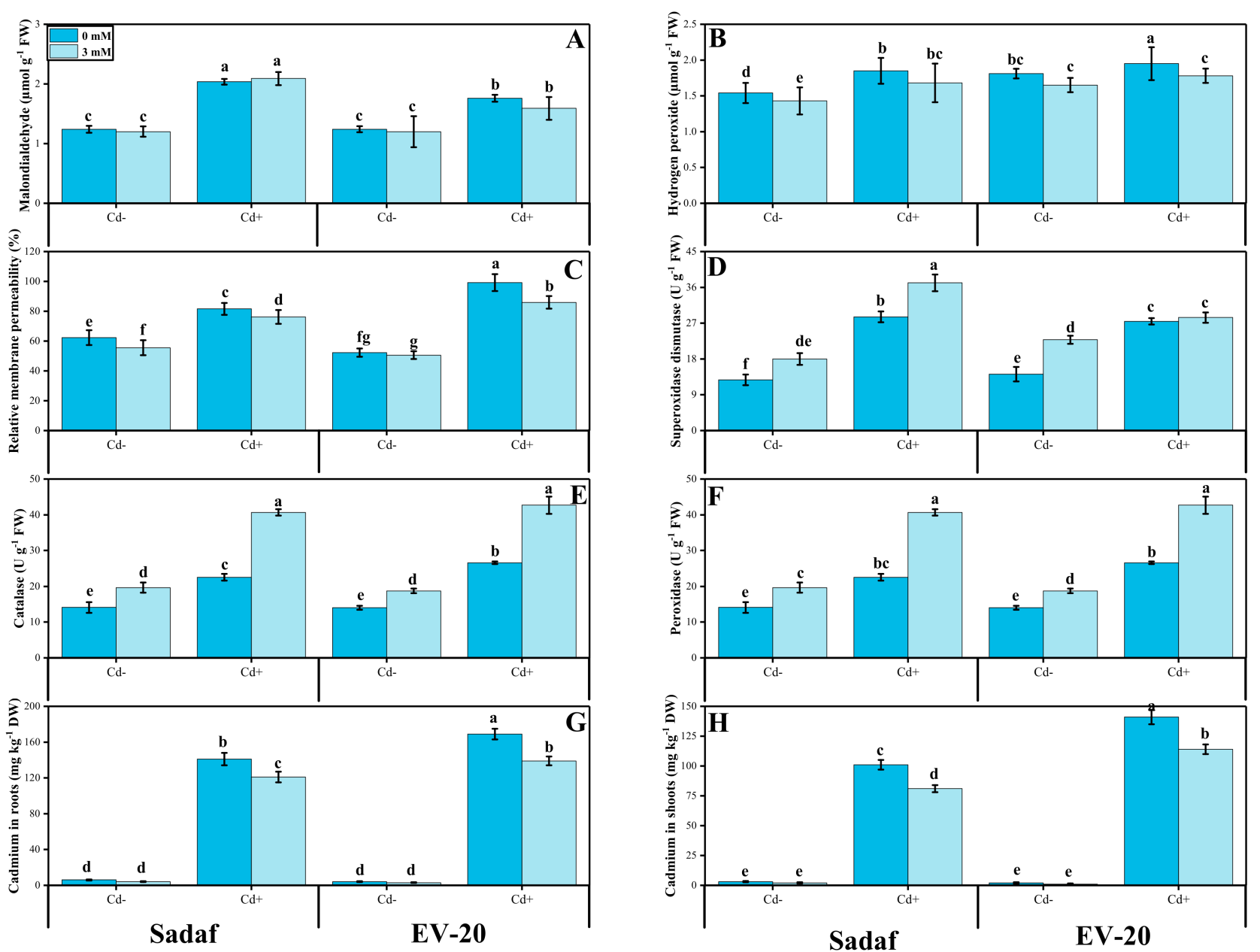

Figure 3. Effect of different levels of $\mathrm{Si}(0$ and $6 \mathrm{mM})$ on malondialdehyde (A), hydrogen peroxide (B), relative membrane permeability (C), superoxide dismutase SOD (D), catalase CAT (E), peroxide POD $(\mathbf{F})$, cadmium concentration in the roots $(\mathbf{G})$ and cadmium concentration in the shoots $(\mathbf{H})$ under the toxic concentration of $\mathrm{Cd}(500 \mu \mathrm{M})$ in the sand in both cultivars of Z. mays (Sadaf and EV-20). All the data represented are the average of three replications $(n=3)$. Error bars represent the standard deviation (SD) of three replicates. Different lowercase letters on the error bars indicate a significant difference between the treatments.

\subsection{Cd Accumulation}

The concentration of $\mathrm{Cd}$ was additionally detected from the roots and shoots of Sadaf and EV-20 with or without the foliar application of $\mathrm{Si}$ when grown in sand containing the toxic concentration of Cd (Figure 3; Table 3). Results from the present study showed that the toxic concentration of $\mathrm{Cd}$ in the sand significantly $(p<0.05)$ increased Cd uptake in the roots and shoots of both cultivars of $Z$. mays compared with the plants which were grown without the addition of $\mathrm{Cd}$ in the sand. In addition, increased concentration of $\mathrm{Cd}$ in the 
sand induced a significant increase of Cd accumulation in the roots $\left(141\right.$ and $169 \mathrm{mg} \mathrm{kg}^{-1}$ in Sadaf and EV-20, respectively), and shoots (101 and $141 \mathrm{mg} \mathrm{kg}^{-1}$ in Sadaf and EV-20, respectively), while; EV-20 accumulated in a higher amount of Cd than Sadaf, and the values for both bioaccumulation factor (BAF) and translocation factor (TF) at all treatments were less than 1. (Figure 3; Tables 3 and 4). Moreover, results showed that $\mathrm{Si}$ application decreased the levels of $\mathrm{Cd}$ in the roots and shoots of the plants compared with plants which were not treated with $\mathrm{Si}$. The decrease in $\mathrm{Cd}$ accumulation was observed in both varieties of Z. mays (Sadaf and EV-20) under the controlled treatment or Cd-stressed environment (Figure 3; Table 3). Similarly, application of Si also decreased the values of BAF (roots and shoots) and TF in both cultivars of Z. mays when grown in the Cd-contaminated sand mixture (Table 4).

Table 3. Mean square values from ANOVA of data for foliar applied silicon oxidative defense system and $\mathrm{Cd}$ uptake in $\mathrm{Z}$. mays cultivars under the cadmium-contaminated soil.

\begin{tabular}{llllllllll}
\hline Source of Variance & df & MDA & RMP & $\mathbf{H}_{\mathbf{2}} \mathbf{O}_{2}$ & SOD & POD & CAT & Cd-R & Cd-S \\
\hline Varieties (V) & 1 & $0.16^{*}$ & $0.06 \mathrm{~ns}$ & $0.083 \mathrm{~ns}$ & $5.76 \mathrm{~ns}$ & $734.78^{* * *}$ & $8.57 \mathrm{~ns}$ & $0.14^{* *}$ & $0.13^{* *}$ \\
Cd stress (S) & 1 & $6.27^{* * *}$ & $6.70^{* * *}$ & $1.03 \mathrm{~ns}$ & $1085.52^{* * *}$ & $588.89^{* * *}$ & $1730.47^{* * *}$ & $0.436^{* * *}$ & $0.219^{* * *}$ \\
Treatments (T) & 1 & $5.13^{* * *}$ & $6.35^{* * *}$ & $1.30^{* *}$ & $204.71^{* *}$ & $54.84^{* *}$ & $839.16^{* *}$ & $0.566^{* * *}$ & $0.467^{* *}$ \\
$\mathrm{~V} \times \mathrm{S}$ & 1 & $0.02^{\mathrm{ns}}$ & $0.08 \mathrm{~ns}$ & $0.03 \mathrm{~ns}$ & $87.30 \mathrm{~ns}$ & $14.07 \mathrm{~ns}$ & $19.67 \mathrm{~ns}$ & $0.624^{* *}$ & $0.246^{* *}$ \\
$\mathrm{~V} \times \mathrm{T}$ & 1 & $0.13 \mathrm{~ns}$ & $0.03 \mathrm{~ns}$ & $2.34^{* *}$ & $5.66^{* * *}$ & $9.66 \mathrm{~ns}$ & $2.067 \mathrm{~ns}$ & $0.008 \mathrm{~ns}$ & $0.04 \mathrm{~ns}$ \\
$\mathrm{~S} \times \mathrm{T}$ & 1 & $0.07^{* *}$ & $0.12^{* *}$ & $0.05 \mathrm{~ns}$ & $8.13^{* * *}$ & $36.58^{* *}$ & $314.07^{* * *}$ & $0.476^{* * *}$ & $0.268^{* * *}$ \\
$\mathrm{~V} \times \mathrm{S} \times \mathrm{T}$ & 1 & $0.09 \mathrm{~ns}$ & 0.02 & $0.04 \mathrm{~ns}$ & $47.32^{*}$ & $83.92^{* * *}$ & $1.55 \mathrm{~ns}$ & $0.746^{* *}$ & $0.67^{* * *}$ \\
Error & 16 & 0.06 & 0.17 & 0.14 & 7.27 & 19.13 & 3.45 & 16.4 & 5.6 \\
\hline
\end{tabular}

$*, * * * * * *$ significant at $0.05,0.01$ and 0.001 levels, respectively. $\mathrm{ns}=$ non-significant. Abbreviations: MDA = malondialdehyde; $\mathrm{RMP}=$ Relative membrane permeability; $\mathrm{H}_{2} \mathrm{O}_{2}$ = hydrogen peroxide; $\mathrm{SOD}=$ superoxide dismutase; $\mathrm{POD}=$ peroxidase; $\mathrm{CAT}=$ catalase $; \mathrm{Cd}-\mathrm{R}=$ Cadmium concentration in the roots and $; \mathrm{Cd}-\mathrm{S}=\mathrm{Cadmium}$ concentration in the shoots.

Table 4. Effect of Si application on bioaccumulation factor (BAF) and translocation factor (TF) of different varieties of $Z$. mays grown under the cadmium-contaminated soil.

\begin{tabular}{ccccc}
\hline Treatments & Varieties & BAF (Roots) & BAF (Shoots) & TF \\
\hline & Sadaf & & & \\
$\mathrm{Cd}+\mathrm{Si}-$ & & 0.28 & 0.20 & 0.71 \\
$\mathrm{Cd}+\mathrm{Si}+$ & \multirow{2}{*}{ EV-20 } & 0.24 & 0.16 & 0.66 \\
$\mathrm{Cd}+\mathrm{Si}-$ & & 0.33 & 0.28 & 0.83 \\
$\mathrm{Cd}+\mathrm{Si}+$ & & 0.27 & 0.22 & 0.82 \\
\hline
\end{tabular}

Different treatments used in the table are as follows: $\mathrm{Cd}+\mathrm{Si}-(\mathrm{Cd}=500 \mu \mathrm{M}+\mathrm{Si}=0 \mathrm{mM})$ and $\mathrm{Cd}+\mathrm{Si}+(\mathrm{Cd}=500 \mu \mathrm{M}$ $+\mathrm{Si}=3 \mathrm{mM})$

\subsection{Relationship between Various Morpho-Physiological Parameters with Cd Uptake and} Accumulation in the Various Parts of the Plants

A Pearson's correlation was illustrated to depict a relationship between various growth and physiological parameters of $Z$. mays cultivars grown under $C d$ stress with or without the foliar application of $\mathrm{Si}$ (Figure 4). As both varieties showed the same trend under a Cd-stressed environment, thus we have studied the tolerant variety i.e., Sadaf in this relationship. Cd concentration in the root was positively correlated with CAT, POD, RMP, MDA, SOD, $\mathrm{H}_{2} \mathrm{O}_{2}$ and $\mathrm{Cd}$ concentration in the shoots while negatively correlated with Chl-a, TC, Carot, SDW, SFW, RFW, Chl-b, RDW, SL and RL. Similarly, Cd concentration in the shoots were positively correlated with CAT, POD, RMP, MDA, SOD, $\mathrm{H}_{2} \mathrm{O}_{2}$ and Cd concentration in the roots while negatively correlated with Chl-a, TC, Carot, SDW, SFW, RFW, Chl-b, RDW, SL and RL. This relationship showed a close connection between various growth parameters studied in this experiment. 


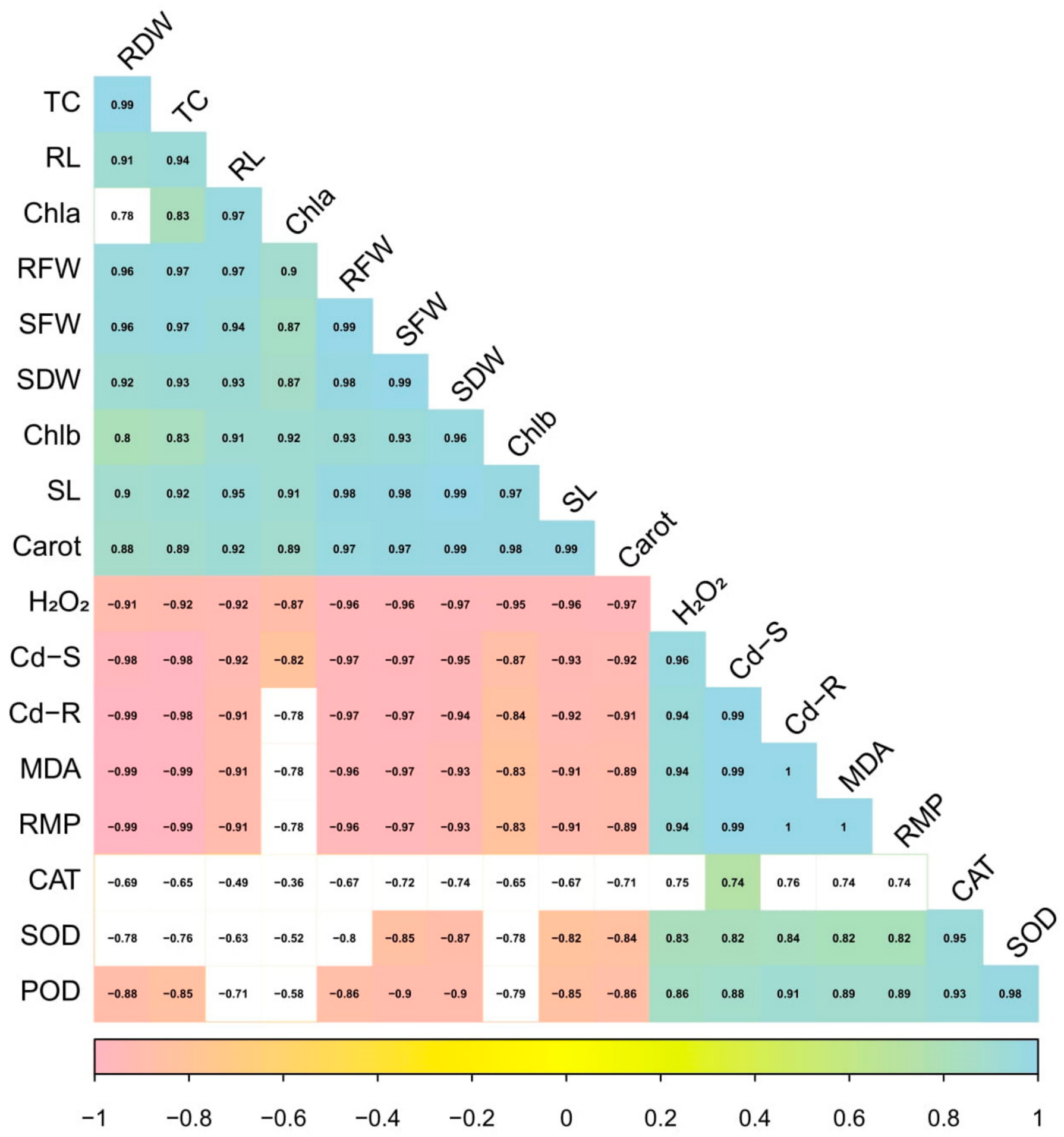

Figure 4. Pearson's correlation between various morpho-physio-biochemical attributes of Z. mays cultivars grown under the application of $\mathrm{Si}$ in $\mathrm{Cd}$-contaminated soil. Different abbreviations used in the figure are as follows: TC (total chlorophyll content), RL (root length), Chla (chlorophyll a content), RFW (root fresh weight), SFW (shoot fresh weight), SDW (shoot dry weight), Chlb (chlorophyll b content), SL (shoot length), Carot (carotenoid content), $\mathrm{H}_{2} \mathrm{O}_{2}$ (hydrogen peroxide content), Cd-S (cadmium concentration in the shoots), Cd-R (cadmium concentration in the roots), MDA (malondialdehyde content), RMP (relative membrane permeability), CAT (catalase activity), SOD (superoxidase activity) and POD (peroxidase activity). 


\subsection{Principal Component Analysis}

The loading plots of principal component analysis (PCA) depicted a close connection between various growth and physiological parameters in Z. mays under the application of $\mathrm{Si}$ in a Cd-stressed environment as presented in Figure 5. Among the entire database, Dim1 and Dim2 exhibited the maximum contribution and occupied more than $96 \%$ of the database. Among which Dim1 exhibited (89.4\%) and Dim2 exhibited (6.7\%) of contributions from the total database. All studied parameters were distributed successfully in the database which gave a clear indication that $\mathrm{Cd}$ stress caused a significant impact to the growth and eco-physiology of Z. mays. From the results, it can be indicated that $\mathrm{Cd}$ concentration in the roots, CAT, POD, RMP, MDA, SOD, $\mathrm{H}_{2} \mathrm{O}_{2}$ and $\mathrm{Cd}$ concentration in the shoots were positively correlated in the database. While; Chl-a, TC, Carot, SDW, SFW, RFW, Chl-b, RDW, SL and RL were negatively correlated, when compared with all other variables in the database.

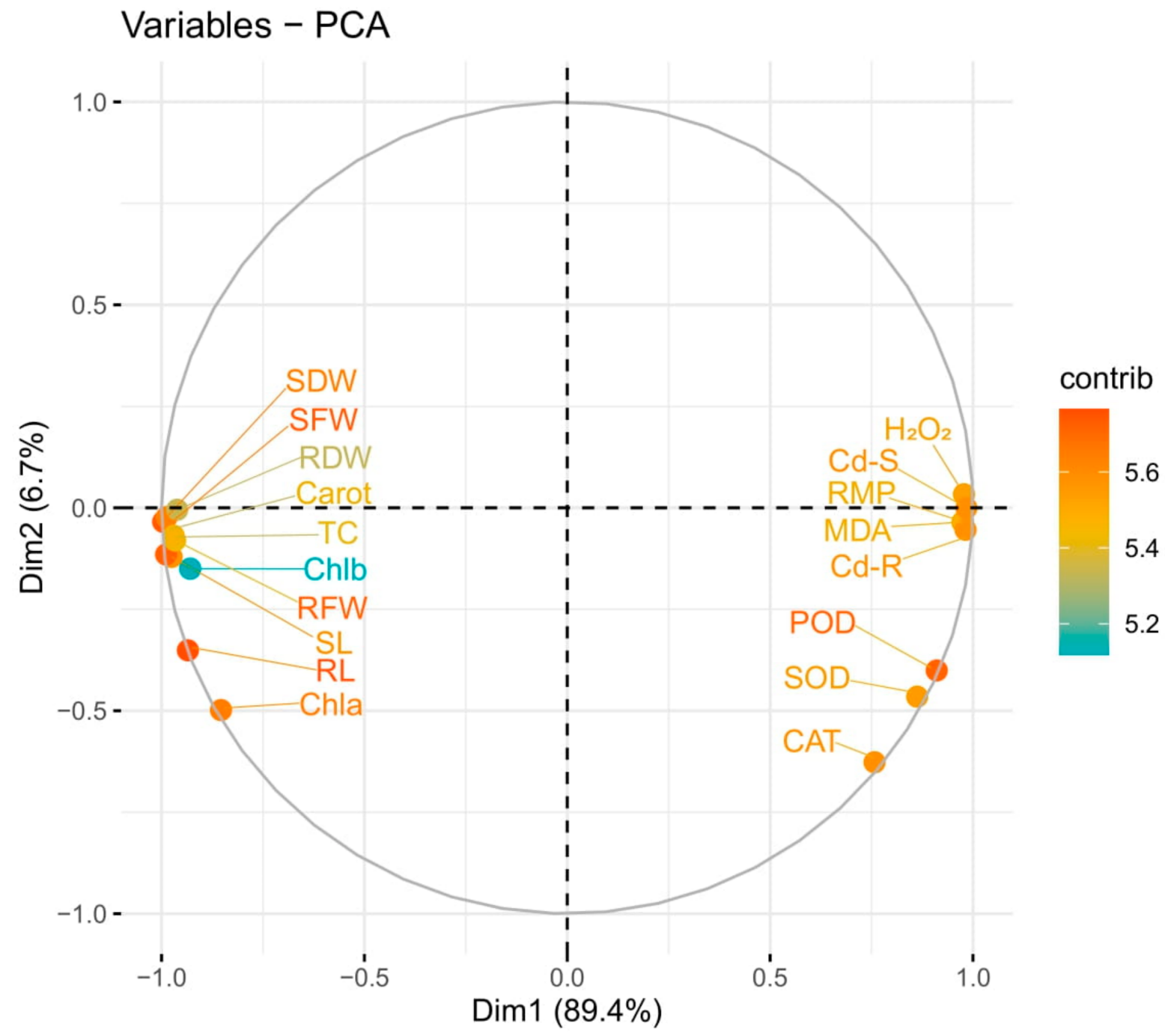

Figure 5. The loading plots of principal component analysis of Z. mays under the application of Si with or without the toxic concentration of $\mathrm{Cd}$ in the sand. Different abbreviations used in the figure are as follows: TC (total chlorophyll content), RL (root length), Chla (chlorophyll a content), RFW (root fresh weight), SFW (shoot fresh weight), SDW (shoot dry weight), Chlb (chlorophyll b content), $\mathrm{SL}$ (shoot length), Carot (carotenoid content), $\mathrm{H}_{2} \mathrm{O}_{2}$ (hydrogen peroxide content), Cd-S (cadmium concentration in the shoots), Cd-R (cadmium concentration in the roots), MDA (malondialdehyde content), RMP (relative membrane permeability), CAT (catalase activity), SOD (superoxidase activity) and POD (peroxidase activity). 


\section{Discussion}

Heavy metal contamination of the environment through anthropogenic activities and/or natural processes presents a widespread and serious problem [40,41]. Heavy metals occur in various forms in soil, which differ greatly with respect to their solubility and bioavailability. The geochemical behavior of heavy metals in soil, their uptake by plants, and effects on crop productivity are affected by various physicochemical properties of soil $[42,43]$. Subsequently, the plants grown in soil containing high levels of Cd showed visible symptoms of injury reflected in terms of chlorosis, growth inhibition, browning of root tips and eventually death [44]. The inhibiting effect of $\mathrm{Cd}$ on fresh and dry mass accumulation, height, root length, leaf area, and other biometric parameters of plants were reported in almost all investigations. Differences in the degree of expressed phytotoxicity due to various $\mathrm{Cd}$ concentrations applied to the root medium, the duration of treatment, as well as the characteristics of species and cultivars were established [12,45]. Cd inhibited the growth of most plant species $[10,44,46]$. Moreover, in the present study we observed the same pattern, i.e., root length, shoot length, root fresh weight, shoot fresh weight, root dry weight and shoot dry weight (Figure 1) and also decreased chlorophyll a, chlorophyll b, total chlorophyll and carotenoid content (Figure 2) in both varieties of Z. mays. Decreased plant growth and biomass under excess $\mathrm{Cd}$ exposure in plants has already been reported as a phenomenon in many studies dependent upon the number of environmental factors including plant species, treatments, growth medium and soil-Cd contents $[10,12,45]$. Plant growth and biomass variation under the same environmental conditions in different $Z$. mays cultivars might be due to the low availability of water, poor stomatal regulation, and perturbed root architecture as described by Saleem et al., [47] in Cu-contaminated soil. These results coincide with the findings of Bashir et al., [48] in Oryza sativa, Rizwan et al., [49] in Triticum turgidum and Javed et al., [50] in Z. mays. Excessive Cd concentrations affected the level of net photosynthesis due to two important factors; (i) stomatal factors and (ii) non-stomatal factors. Ascorbic acid mediated the closure of the stomata under excess concentration of $\mathrm{Cd}$ and caused a reduction in stomatal numbers under the influence of stomatal factors $[48,51]$.

Stress conditions can disturb the dynamic equilibrium of reactive oxygen species (ROS) production and elimination under normal growth in plants [52-54], which promotes ROS accumulation and membrane lipid peroxidation, and disrupts the structure and function of the cell membrane system $[55,56]$. It was reported that an excess of $\mathrm{Cd}$ can increase lipid peroxidation and MDA, an oxidized product of membrane lipids, indicating the prevalence of oxidative stress and membrane damage $[12,44,46]$. This ROS accumulation in plants is removed by a variety of antioxidant enzymes such as superoxide dismutase (SOD), peroxidase (POD) and catalase (CAT) which were also increased in the plants grown in the toxic concentration of $\mathrm{Cd}(500 \mu \mathrm{M})$, compared with the plants grown in Cd-free sand (Figure 3). However, the expression of antioxidative enzymes, such as SOD, POD and CAT under a Cd-stressed environment plays a significant role in reducing $\mathrm{Cd}$ toxicity, which was reported in a number of studies among various plant species $[45,46,48]$. Our results were similar to those of the study undertaken by Howlader et al., [20] which showed that Cd-treated plants boosted the endogenous levels of antioxidants SOD, POD, CAT, which detoxified ROS at the cellular level. In the present study, we additionally noticed that the $\mathrm{Cd}$ concentration in the plant parts were increased by an increasing concentration of $\mathrm{Cd}$ in the sand (Figure 3). It is well known that $\mathrm{Cd}$ toxicity in crops depend on the bioavailability of $\mathrm{Cd}$ in soils and the concentration of elements, which can compete with $\mathrm{Cd}$ during plant uptake [57]. Cd uptake in Z. mays plants varies with soil $\mathrm{pH}$ and organic matter content present in the soil [58]. After absorption by the roots, Cd is transported to the stele by passing through the endodermis, and Casparian strips, where the $\mathrm{Cd}$ is then translocated to the shoot via xylem and finally accumulates in the grains $[5,11]$. The translocation factor (TF) and bioaccumulation factor (BCF) are important in screening hyperaccumulators for phytoremediation of heavy metals [59]. Screening of hyperaccumulators depend on BCF and TF values (both of them are greater than 1) for evaluation and selection of plants for 
phytoremediation $[60,61]$. The TF is the capacity of plants to transfer metals from roots to shoots and BCF expresses the ability of plants to accumulate metals from the soil to tissues [62,63]. Another requirement for the criteria of plants that determine whether it qualifies as a $\mathrm{Cd}$ hyperaccumulator species or not, is $\mathrm{Cd}$ accumulation in shoots. Although, in the present study we noted that the BAF and TF values were less than 1 (Table 4), which shows that both $Z$. mays cultivars are not hyperaccumulator species for $\mathrm{Cd}$. Similar results for Z. mays were also displayed by Anwer et al., [64], and Tanwir et al., [65] where they found $\mathrm{Cd}$ accumulated highly in the roots then transferred to the shoots which depicts Z. mays as not being a hyperaccumulator species for Cd-contaminated soil.

Silicon (Si) is found abundantly in the earth's crust and is believed to be an important constituent in soil where it efficiently neutralizes the hazardous impacts of different stresses such as salinity, temperature and various metal stresses on plants [49]. Although, $\mathrm{Si}$ is not deliberated as an indispensable plant nutrient but rather plays a major role in plant growth, especially under stressful conditions [11]. Silicon bears an ability to be promptly transported through specified transporters located in the cellular membranes of plant roots, and translocation from root cells to the aerial parts of plants is carried out through influx transporters identified in the xylem parenchyma cells [20,21]. Numerous investigations have reported the ameliorating effects of Si against heavy metals in Triticum aestivum [5], Trachyspermum ammi [11] and Triticum turgidum [66]. Under conditions of metal stress, the application of Si reduced the metal contents of plant organs and increased plant growth and composition, improved photosynthetic machinery, decreased in planta oxidative stress via increased antioxidative compounds, increased uptake of minerals and influenced the exudation of organic acids from plant roots which were discussed in detail in reviews by Adrees et al., [67] and Jia-Wen et al., [25]. Research findings depicted that the application of Si increased plant growth and biomass (Figure 1), and also increased photosynthetic pigments (Figure 2) in both Z. mays cultivars grown under the Cd-contaminated soil. The application of Si bears a protective role and increases plant morphology and physiology under Cd [68], Cu [69] and Zn [23] stress. This might result from the fact that Si application leads to a secretion of secondary metabolites which assist in ameliorating metal stressed conditions and additionally due to the dilution effects of Si application which increase morpho-physiological traits by decreasing the contents of $\mathrm{Cd}$ in plant roots and shoots $[24,25,67]$. The oxidative stress in plant cells and tissues can be reduced by the application of Si which increases the activities of antioxidants and capturing of stress induced ROS $[5,20,21]$. Our results illustrated that Si application decreased oxidative stress indicators (Figure 3 ) and increased the activities of various antioxidant compounds such as SOD, POD and CAT in both varieties of Z. mays (Figure 3). The application of Si induces the activities of antioxidative enzymes and, therefore, can be considered as an indicator of enhanced ROS production and extenuation (Figure 3). Moreover, our results showed that the application of Si decreased the uptake of $\mathrm{Cd}$ concentration in the roots and shoots of both Z. mays cultivars under Cd-contaminated sand (Figure 3). This might be due to the Si restricting apoplasmic transport of heavy metals and thus decreasing the concentration of free $\mathrm{Cd}$ ions in apoplasm [58,70]. The schematic presentation of mechanistic role of $\mathrm{Si}$ alleviating the Cd toxicity in Z. mays is presented in Figure 6. 

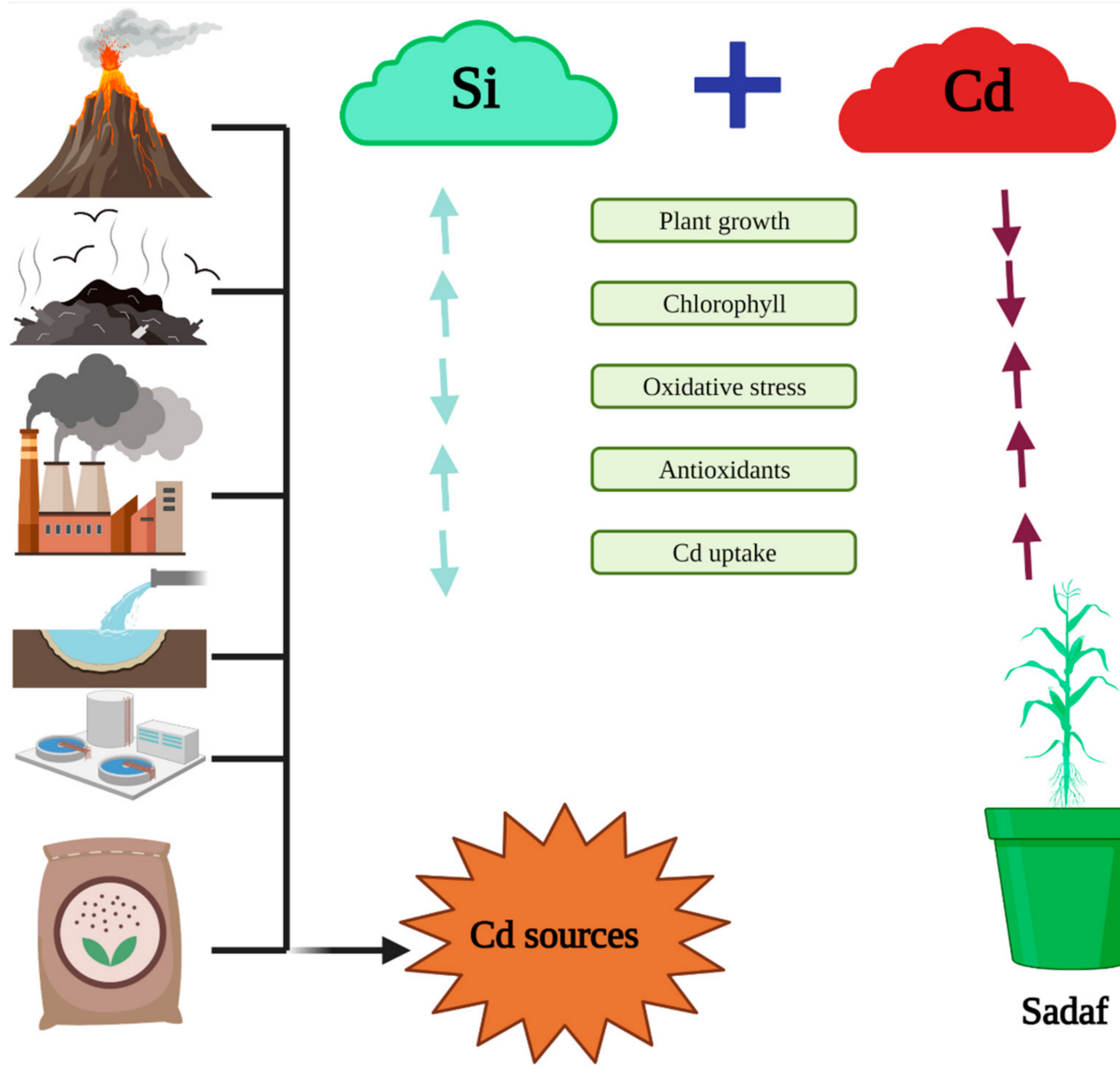

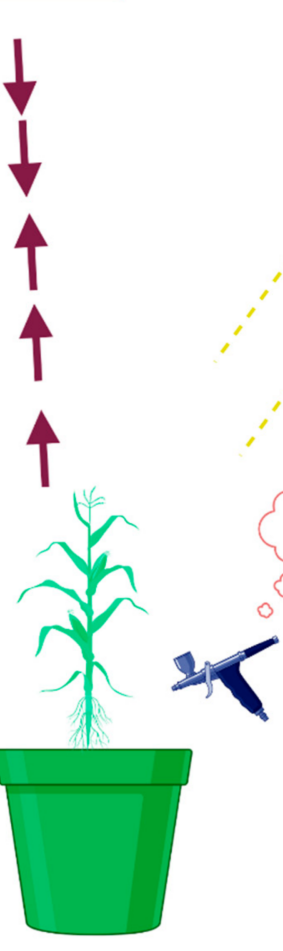

Sadaf

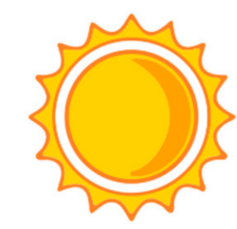

$\mathrm{Si}$

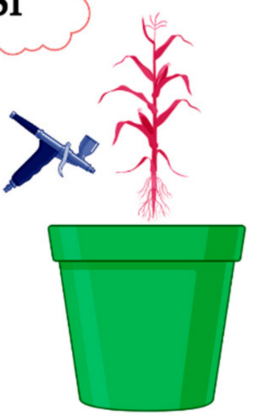

EV-20

Figure 6. Schematic presentation interpreting the mechanistic role of $\mathrm{Si}$ in alleviating the Cd toxicity in Z. mays. The Cd toxicity inhibited plant growth characteristics and higher $\mathrm{Cd}$ concentration was accumulated in the roots and shoots of Z. mays. In contrast, the application of Si significantly alleviated $C d$ toxicity and improved root and shoot growth and alleviated Cd induced inhibition of photosynthetic efficiency. Si addition regulated the antioxidant defense system while reduced the oxidative stress and relative membrane permeability. The current study demonstrated that Si could relieve $\mathrm{Cd}$ toxicity in $\mathrm{Z}$. mays by reducing $\mathrm{Cd}$ uptake at the root surface and its translocation (root to shoot), and regulating proficient antioxidant coordination in the leaves of Z. mays.

\section{Conclusions}

On the basis of these findings, it can be concluded that the negative impact of $\mathrm{Cd}$ toxicity can be overcome by the application of Si. Moreover, our results depicted that $\mathrm{Cd}$ toxicity induced severe metal toxicity in Z. mays cultivars by increased generation of ROS in the form of oxidative stress and increased the concentration of $C d$ in the roots and shoots of the plants, which ultimately decreased plant growth and yield and photosynthetic efficiency. In addition, we noticed that the values of BAF and TF were less than 1 which revealed that $Z$. mays cultivars were not a hyperaccumulator species of the $\mathrm{Cd}$-contaminated environment. Hence, $\mathrm{Cd}$ toxicity was eliminated by the external application of Si, which also decreased the Cd concentration in the plant tissues, degenerated ROS, and increased the activities of antioxidants. Therefore, long-term field studies should be executed to draw parallels among plants and crops root exudations, metal stress, nutrient mobility patterns, and plant growth in order to gain further insights into underlying mechanisms.

Author Contributions: Conceptualization, A.P.; Data curation, A.P.; Formal analysis, I.H. and X.W.; Funding acquisition, I.H., X.W., H.A. and M.A.E.-S.; Investigation, I.H.; Methodology, A.P.; Project administration, S.U.K. and M.A.E.-S.; Resources, A.P. and S.U.K.; Software, M.H.S.; Supervision, 
S.A.; Visualization, M.H.S.; Writing—original draft, M.H.S., S.U.K., X.W., H.A., M.A.E.-S. and S.A.; Writing-review \& editing, M.H.S., M.A.E.-S. and S.A. All authors have read and agreed to the published version of the manuscript.

Funding: The authors highly acknowledge the Government College University, Faisalabad, Pakistan for their financial support to complete this project. The authors would like to extend their sincere appreciation to the Researchers Supporting Project No (RSP-2021/182) King Saud University, Riyadh, Saudi Arabia.

Institutional Review Board Statement: Not applicable.

Informed Consent Statement: Not applicable.

Data Availability Statement: Not applicable.

Acknowledgments: The authors would like to extend their sincere appreciation to the Researchers Supporting Project No (RSP-2021/182) King Saud University, Riyadh, Saudi Arabia.

Conflicts of Interest: The authors declare that there are no conflict of interest.

\section{References}

1. Zaheer, I.E.; Ali, S.; Saleem, M.H.; Imran, M.; Alnusairi, G.S.H.; Alharbi, B.M.; Riaz, M.; Abbas, Z.; Rizwan, M.; Soliman, M.H. Role of iron-lysine on morpho-physiological traits and combating chromium toxicity in rapeseed (Brassica napus L.) plants irrigated with different levels of tannery wastewater. Plant Physiol. Biochem. 2020, 155, 70-84. [CrossRef] [PubMed]

2. Ahmad, S.; Mfarrej, M.F.B.; El-Esawi, M.A.; Waseem, M.; Alatawi, A.; Nafees, M.; Saleem, M.H.; Rizwan, M.; Yasmeen, T.; Anayat, A.; et al. Chromium-resistant Staphylococcus aureus alleviates chromium toxicity by developing synergistic relationships with zinc oxide nanoparticles in wheat. Ecotoxicol. Environ. Saf. 2022, 230, 113142. [CrossRef] [PubMed]

3. Imran, M.; Hussain, S.; El-Esawi, M.A.; Rana, M.S.; Saleem, M.H.; Riaz, M.; Ashraf, U.; Potcho, M.P.; Duan, M.; Rajput, I.A. Molybdenum Supply Alleviates the Cadmium Toxicity in Fragrant Rice by Modulating Oxidative Stress and Antioxidant Gene Expression. Biomolecules 2020, 10, 1582. [CrossRef] [PubMed]

4. Imran, M.; Hussain, S.; Rana, M.S.; Saleem, M.H.; Rasul, F.; Ali, K.H.; Potcho, M.P.; Pan, S.; Duan, M.; Tang, X. Molybdenum improves 2-acetyl-1-pyrroline, grain quality traits and yield attributes in fragrant rice through efficient nitrogen assimilation under cadmium toxicity. Ecotoxicol. Environ. Saf. 2021, 211, 111911. [CrossRef]

5. Heile, A.O.; Zaman, Q.u.; Aslam, Z.; Hussain, A.; Aslam, M.; Saleem, M.H.; Abualreesh, M.H.; Alatawi, A.; Ali, S. Alleviation of Cadmium Phytotoxicity Using Silicon Fertilization in Wheat by Altering Antioxidant Metabolism and Osmotic Adjustment. Sustainability 2021, 13, 11317. [CrossRef]

6. Rizwan, M.; Ali, S.; Abbas, T.; Zia-ur-Rehman, M.; Hannan, F.; Keller, C.; Al-Wabel, M.I.; Ok, Y.S. Cadmium minimization in wheat: A critical review. Ecotoxicol. Environ. Saf. 2016, 130, 43-53. [CrossRef]

7. Madhu, P.M.; Sadagopan, R.S. Effect of Heavy Metals on Growth and Development of Cultivated Plants with Reference to Cadmium, Chromium and Lead-A Review. J. Stress Physiol. Biochem. 2020, 16, 84-102.

8. Afzal, J.; Saleem, M.H.; Batool, F.; Elyamine, A.M.; Rana, M.S.; Shaheen, A.; El-Esawi, M.A.; Tariq Javed, M.; Ali, Q.; Arslan Ashraf, M.; et al. Role of Ferrous Sulfate $\left(\mathrm{FeSO}_{4}\right)$ in Resistance to Cadmium Stress in Two Rice (Oryza sativa L.) Genotypes. Biomolecules 2020, 10, 1693. [CrossRef]

9. Afzal, J.; Wang, X.; Saleem, M.-H.; Sun, X.; Hussain, S.; Khan, I.; Rana, M.-S.; Ahmed, S.; Awan, S.-A.; Fiaz, S.; et al. Application of ferrous sulfate alleviates negative impact of cadmium in rice (Oryza sativa L.). Biocell 2021, 45, 1631-1649. [CrossRef]

10. Ahmad, P.; Ahanger, M.A.; Alyemeni, M.N.; Wijaya, L.; Alam, P. Exogenous application of nitric oxide modulates osmolyte metabolism, antioxidants, enzymes of ascorbate-glutathione cycle and promotes growth under cadmium stress in tomato. Protoplasma 2018, 255, 79-93. [CrossRef]

11. Javed, M.T.; Saleem, M.H.; Aslam, S.; Rehman, M.; Iqbal, N.; Begum, R.; Ali, S.; Alsahli, A.A.; Alyemeni, M.N.; Wijaya, L. Elucidating silicon-mediated distinct morpho-physio-biochemical attributes and organic acid exudation patterns of cadmium stressed Ajwain (Trachyspermum ammi L.). Plant Physiol. Biochem. 2020, 157, 23-37. [CrossRef] [PubMed]

12. Alam, P.; Kaur Kohli, S.; Al Balawi, T.; Altalayan, F.H.; Alam, P.; Ashraf, M.; Bhardwaj, R.; Ahmad, P. Foliar Application of 24-Epibrassinolide Improves Growth, Ascorbate-Glutathione Cycle, and Glyoxalase System in Brown Mustard (Brassica juncea (L.) Czern.) under Cadmium Toxicity. Plants 2020, 9, 1487. [CrossRef] [PubMed]

13. Saleem, M.H.; Ali, S.; Rehman, M.; Rana, M.S.; Rizwan, M.; Kamran, M.; Imran, M.; Riaz, M.; Soliman, M.H.; Elkelish, A. Influence of phosphorus on copper phytoextraction via modulating cellular organelles in two jute (Corchorus capsularis L.) varieties grown in a copper mining soil of Hubei Province, China. Chemosphere 2020, 248, 126032. [CrossRef] [PubMed]

14. Parveen, A.; Saleem, M.H.; Kamran, M.; Haider, M.Z.; Chen, J.-T.; Malik, Z.; Rana, M.S.; Hassan, A.; Hur, G.; Javed, M.T. Effect of Citric Acid on Growth, Ecophysiology, Chloroplast Ultrastructure, and Phytoremediation Potential of Jute (Corchorus capsularis L.) Seedlings Exposed to Copper Stress. Biomolecules 2020, 10, 592. [CrossRef] 
15. Nazar, Z.; Akram, N.A.; Saleem, M.H.; Ashraf, M.; Ahmed, S.; Ali, S.; Abdullah Alsahli, A.; Alyemeni, M.N. GlycinebetaineInduced Alteration in Gaseous Exchange Capacity and Osmoprotective Phenomena in Safflower (Carthamus tinctorius L.) under Water Deficit Conditions. Sustainability 2020, 12, 10649. [CrossRef]

16. Kamran, M.; Danish, M.; Saleem, M.H.; Malik, Z.; Parveen, A.; Abbasi, G.H.; Jamil, M.; Ali, S.; Afzal, S.; Riaz, M. Application of abscisic acid and 6-benzylaminopurine modulated morpho-physiological and antioxidative defense responses of tomato (Solanum lycopersicum L.) by minimizing cobalt uptake. Chemosphere 2020, 128169. [CrossRef]

17. Yaseen, R.; Aziz, O.; Saleem, M.H.; Riaz, M.; Zafar-ul-Hye, M.; Rehman, M.; Ali, S.; Rizwan, M.; Nasser Alyemeni, M.; El-Serehy, H.A. Ameliorating the Drought Stress for Wheat Growth through Application of ACC-Deaminase Containing Rhizobacteria along with Biogas Slurry. Sustainability 2020, 12, 6022. [CrossRef]

18. Saleem, M.H.; Rehman, M.; Fahad, S.; Tung, S.A.; Iqbal, N.; Hassan, A.; Ayub, A.; Wahid, M.A.; Shaukat, S.; Liu, L.; et al. Leaf gas exchange, oxidative stress, and physiological attributes of rapeseed (Brassica napus L.) grown under different light-emitting diodes. Photosynthetica 2020, 58, 836-845. [CrossRef]

19. Zaheer, I.E.; Ali, S.; Saleem, M.H.; Arslan Ashraf, M.; Ali, Q.; Abbas, Z.; Rizwan, M.; El-Sheikh, M.A.; Alyemeni, M.N.; Wijaya, L. Zinc-lysine Supplementation Mitigates Oxidative Stress in Rapeseed (Brassica napus L.) by Preventing Phytotoxicity of Chromium, When Irrigated with Tannery Wastewater. Plants 2020, 9, 1145. [CrossRef]

20. Howladar, S.M.; Al-Robai, S.A.; Al-Zahrani, F.S.; Howladar, M.M.; Aldhebiani, A.Y. Silicon and its application method effects on modulation of cadmium stress responses in Triticum aestivum (L.) through improving the antioxidative defense system and polyamine gene expression. Ecotoxicol. Environ. Saf. 2018, 159, 143-152. [CrossRef]

21. Ahmad, P.; Abdel Latef, A.A.; Abd_Allah, E.F.; Hashem, A.; Sarwat, M.; Anjum, N.A.; Gucel, S. Calcium and potassium supplementation enhanced growth, osmolyte secondary metabolite production, and enzymatic antioxidant machinery in cadmium-exposed chickpea (Cicer arietinum L.). Front. Plant Sci. 2016, 7, 513. [CrossRef] [PubMed]

22. Parveen, A.; Liu, W.; Hussain, S.; Asghar, J.; Perveen, S.; Xiong, Y. Silicon priming regulates morpho-physiological growth and oxidative metabolism in maize under drought stress. Plants 2019, 8, 431. [CrossRef] [PubMed]

23. Anwaar, S.A.; Ali, S.; Ali, S.; Ishaque, W.; Farid, M.; Farooq, M.A.; Najeeb, U.; Abbas, F.; Sharif, M. Silicon (Si) alleviates cotton (Gossypium hirsutum L.) from zinc (Zn) toxicity stress by limiting Zn uptake and oxidative damage. Environ. Sci. Pollut. Res. 2015, 22, 3441-3450. [CrossRef] [PubMed]

24. Siddiqui, H.; Ahmed, K.B.M.; Sami, F.; Hayat, S. Silicon nanoparticles and plants: Current knowledge and future perspectives. In Sustainable Agriculture Reviews 41; Hayat, S., Pichtel, J., Faizan, M., Fariduddin, Q., Eds.; Springer: Cham, Switzerland, 2020; pp. 129-142.

25. Wu, J.-W.; Shi, Y.; Zhu, Y.-X.; Wang, Y.-C.; Gong, H.-J. Mechanisms of enhanced heavy metal tolerance in plants by silicon: A review. Pedosphere 2013, 23, 815-825. [CrossRef]

26. Hasanuzzaman, M.; Nahar, K.; Anee, T.I.; Fujita, M. Exogenous silicon attenuates cadmium-induced oxidative stress in Brassica napus L. by modulating AsA-GSH pathway and glyoxalase system. Front. Plant Sci. 2017, 8, 1061. [CrossRef]

27. Nawaz, M.; Wang, X.; Saleem, M.H.; Khan, M.H.U.; Afzal, J.; Fiaz, S.; Ali, S.; Ishaq, H.; Khan, A.H.; Rehman, N.; et al. Deciphering Plantago ovata Forsk Leaf Extract Mediated Distinct Germination, Growth and Physio-Biochemical Improvements under Water Stress in Maize (Zea mays L.) at Early Growth Stage. Agronomy 2021, 11, 1404. [CrossRef]

28. Xing, Y.; Zhang, T.; Jiang, W.; Li, P.; Shi, P.; Xu, G.; Cheng, S.; Cheng, Y.; Fan, Z.; Wang, X. Effects of irrigation and fertilization on different potato varieties growth, yield and resources use efficiency in the Northwest China. Agri. Waste Manag. 2021, 107351. [CrossRef]

29. Anwar, S. Chelators induced uptake of cadmium and modulation of water relation, antioxidants and photosynthetic traits of maize. Environ. Sci. Pollut. Res. 2019, 26, 17577-17590. [CrossRef]

30. Anwar, S.; Khan, S.; Ashraf, M.Y.; Noman, A.; Zafar, S.; Liu, L.; Ullah, S.; Fahad, S. Impact of chelator-induced phytoextraction of cadmium on yield and ionic uptake of maize. Int. J. Phytoremediat. 2017, 19, 505-513. [CrossRef]

31. Hoagland, D.R.; Arnon, D.I. Growing plants without soil by the water-culture method. Grow. Plants Without Soil Water-Cult. Method 1938, 347, 16

32. Arnon, D.I. Copper enzymes in isolated chloroplasts. Polyphenoloxidase in Beta vulgaris. Plant Physiol. 1949, 24, 1. [CrossRef] [PubMed]

33. Jana, S.; Choudhuri, M.A. Glycolate metabolism of three submersed aquatic angiosperms: Effect of heavy metals. Aquat. Bot. 1981, 11, 67-77. [CrossRef]

34. Heath, R.L.; Packer, L. Photoperoxidation in isolated chloroplasts: I. Kinetics and stoichiometry of fatty acid peroxidation. Arch. Biochem. Biophys. 1968, 125, 189-198. [CrossRef]

35. Yang, G.; Rhodes, D.; Joly, R.J. Effects of high temperature on membrane stability and chlorophyll fluorescence in glycinebetainedeficient and glycinebetaine-containing maize lines. Funct. Plant Biol. 1996, 23, 437-443. [CrossRef]

36. Chen, C.-N.; Pan, S.-M. Assay of superoxide dismutase activity by combining electrophoresis and densitometry. Bot. Bull. Acad. Sin. 1996, 37, 107-111.

37. Sakharov, I.Y.; Ardila, G.B. Variations of peroxidase activity in cocoa (Theobroma cacao L.) beans during their ripening, fermentation and drying. Food Chem. 1999, 65, 51-54. [CrossRef]

38. Aebi, H. Catalase in vitro. In Methods in Enzymology; Elsevier: Amsterdam, The Netherlands, 1984; Volume 105, pp. 121-126. 
39. Jezek, M.; Geilfus, C.-M.; Mühling, K.-H. Glutamine synthetase activity in leaves of Zea mays L. as influenced by magnesium status. Planta 2015, 242, 1309-1319. [CrossRef]

40. Wang, X.; Fan, J.; Xing, Y.; Xu, G.; Wang, H.; Deng, J.; Wang, Y.; Zhang, F.; Li, P.; Li, Z. The effects of mulch and nitrogen fertilizer on the soil environment of crop plants. Advan. Agro. 2019, 153, 121-173.

41. Tariq, F.; Wang, X.; Saleem, M.H.; Khan, Z.I.; Ahmad, K.; Saleem Malik, I.; Munir, M.; Mahpara, S.; Mehmood, N.; Ahmad, T.; et al. Risk Assessment of Heavy Metals in Basmati Rice: Implications for Public Health. Sustainability 2021, 13, 8513. [CrossRef]

42. Ghani, M.A.; Abbas, M.M.; Ali, B.; Aziz, R.; Qadri, R.W.K.; Noor, A.; Azam, M.; Bahzad, S.; Saleem, M.H.; Abualreesh, M.H.; et al. Alleviating Role of Gibberellic Acid in Enhancing Plant Growth and Stimulating Phenolic Compounds in Carrot (Daucus carota L.) under Lead Stress. Sustainability 2021, 13, 12329. [CrossRef]

43. Saleem, M.H.; Fahad, S.; Khan, S.U.; Ahmar, S.; Khan, M.H.U.; Rehman, M.; Maqbool, Z.; Liu, L. Morpho-physiological traits, gaseous exchange attributes, and phytoremediation potential of jute (Corchorus capsularis L.) grown in different concentrations of copper-contaminated soil. Ecotoxicol. Environ. Saf. 2020, 189, 109915. [CrossRef] [PubMed]

44. Hatamian, M.; Nejad, A.R.; Kafi, M.; Souri, M.K.; Shahbazi, K. Interaction of lead and cadmium on growth and leaf morphophysiological characteristics of European hackberry (Celtis australis) seedlings. Chem. Biol. Technol. Agric. 2020, 7, 9. [CrossRef]

45. Rizwan, M.; Ali, S.; Ali, B.; Adrees, M.; Arshad, M.; Hussain, A.; ur Rehman, M.Z.; Waris, A.A. Zinc and iron oxide nanoparticles improved the plant growth and reduced the oxidative stress and cadmium concentration in wheat. Chemosphere 2019, 214, 269-277. [CrossRef] [PubMed]

46. Tripathi, D.K.; Singh, V.P.; Kumar, D.; Chauhan, D.K. Rice seedlings under cadmium stress: Effect of silicon on growth, cadmium uptake, oxidative stress, antioxidant capacity and root and leaf structures. Chem. Ecol. 2012, 28, 281-291. [CrossRef]

47. Saleem, M.H.; Rehman, M.; Kamran, M.; Afzal, J.; Noushahi, H.A.; Liu, L. Investigating the potential of different jute varieties for phytoremediation of copper-contaminated soil. Environ. Sci. Pollut. Res. 2020, 27, 30367-30377. [CrossRef] [PubMed]

48. Bashir, A.; Rizwan, M.; Ali, S.; ur Rehman, M.Z.; Ishaque, W.; Riaz, M.A.; Maqbool, A. Effect of foliar-applied iron complexed with lysine on growth and cadmium (Cd) uptake in rice under Cd stress. Environ. Sci. Pollut. Res. 2018, 25, 20691-20699. [CrossRef]

49. Rizwan, M.; Meunier, J.-D.; Miche, H.; Keller, C. Effect of silicon on reducing cadmium toxicity in durum wheat (Triticum turgidum L. cv. Claudio, W.) grown in a soil with aged contamination. J. Hazard. Mater. 2012, 209, 326-334. [CrossRef]

50. Javed, M.T.; Akram, M.S.; Tanwir, K.; Chaudhary, H.J.; Ali, Q.; Stoltz, E.; Lindberg, S. Cadmium spiked soil modulates root organic acids exudation and ionic contents of two differentially Cd tolerant maize (Zea mays L.) cultivars. Ecotoxicol. Environ. Saf. 2017, 141, 216-225. [CrossRef]

51. Wang, X.; Wang, G.; Guo, T.; Xing, Y.; Mo, F.; Wang, H.; Fan, J.; Zhang, F. Effects of plastic mulch and nitrogen fertilizer on the soil microbial community, enzymatic activity and yield performance in a dryland maize cropping system. Eurp. J. Soil Sci. 2021, 72, 400-412. [CrossRef]

52. Zaheer, I.E.; Ali, S.; Saleem, M.H.; Noor, I.; El-Esawi, M.A.; Hayat, K.; Rizwan, M.; Abbas, Z.; El-Sheikh, M.A.; Alyemeni, M.N. Iron-Lysine Mediated Alleviation of Chromium Toxicity in Spinach (Spinacia oleracea L.) Plants in Relation to MorphoPhysiological Traits and Iron Uptake When Irrigated with Tannery Wastewater. Sustainability 2020, 12, 6690. [CrossRef]

53. Saleem, M.H.; Kamran, M.; Zhou, Y.; Parveen, A.; Rehman, M.; Ahmar, S.; Malik, Z.; Mustafa, A.; Anjum, R.M.A.; Wang, B. Appraising growth, oxidative stress and copper phytoextraction potential of flax (Linum usitatissimum L.) grown in soil differentially spiked with copper. J. Environ. Manag. 2020, 257, 109994. [CrossRef]

54. Ali, M.; Kamran, M.; Abbasi, G.H.; Saleem, M.H.; Ahmad, S.; Parveen, A.; Malik, Z.; Afzal, S.; Ahmar, S.; Dawar, K.M.; et al. Melatonin-Induced Salinity Tolerance by Ameliorating Osmotic and Oxidative Stress in the Seedlings of Two Tomato (Solanum lycopersicum L.) Cultivars. J. Plant Growth Regul. 2020, 40, 2236-2248. [CrossRef]

55. Rehman, M.; Saleem, M.H.; Fahad, S.; Maqbool, Z.; Peng, D.; Deng, G.; Liu, L. Medium nitrogen optimized Boehmeria nivea L. growth in copper contaminated soil. Chemosphere 2020, 128972. [CrossRef] [PubMed]

56. Rehman, M.; Liu, L.; Bashir, S.; Saleem, M.H.; Chen, C.; Peng, D.; Siddique, K.H. Influence of rice straw biochar on growth, antioxidant capacity and copper uptake in ramie (Boehmeria nivea L.) grown as forage in aged copper-contaminated soil. Plant Physiol. Biochem. 2019, 138, 121-129. [CrossRef] [PubMed]

57. Khalid, H.; Zia-ur-Rehman, M.; Naeem, A.; Khalid, M.U.; Rizwan, M.; Ali, S.; Umair, M.; Sohail, M.I. Solanum nigrum L.: A Novel Hyperaccumulator for the Phyto-Management of Cadmium Contaminated Soils. In Cadmium Toxicity and Tolerance in Plants; Elsevier: Amsterdam, The Netherlands, 2019; pp. 451-477.

58. Zhao, S.; Fan, Z.; Sun, L.; Zhou, T.; Xing, Y.; Liu, L. Interaction effects on uptake and toxicity of perfluoroalkyl substances and cadmium in wheat (Triticum aestivum L.) and rapeseed (Brassica campestris L.) from co-contaminated soil. Ecotoxicol. Environ. Saf. 2017, 137, 194-201. [CrossRef] [PubMed]

59. Saleem, M.H.; Ali, S.; Rehman, M.; Hasanuzzaman, M.; Rizwan, M.; Irshad, S.; Shafiq, F.; Iqbal, M.; Alharbi, B.M.; Alnusaire, T.S. Jute: A Potential Candidate for Phytoremediation of Metals-A Review. Plants 2020, 9, 258. [CrossRef]

60. Saleem, M.H.; Ali, S.; Hussain, S.; Kamran, M.; Chattha, M.S.; Ahmad, S.; Aqeel, M.; Rizwan, M.; Aljarba, N.H.; Alkahtani, S. Flax (Linum usitatissimum L.): A Potential Candidate for Phytoremediation? Biological and Economical Points of View. Plants 2020, 9, 496. [CrossRef] 
61. Saleem, M.H.; Fahad, S.; Khan, S.U.; Din, M.; Ullah, A.; Sabagh, A.E.L.; Hossain, A.; Llanes, A.; Liu, L. Copper-induced oxidative stress, initiation of antioxidants and phytoremediation potential of flax (Linum usitatissimum L.) seedlings grown under the mixing of two different soils of China. Environ. Sci. Pollut. Res. 2020, 27, 5211-5221. [CrossRef]

62. Saleem, M.H.; Ali, S.; Irshad, S.; Hussaan, M.; Rizwan, M.; Rana, M.S.; Hashem, A.; Abd_Allah, E.F.; Ahmad, P. Copper Uptake and Accumulation, Ultra-Structural Alteration, and Bast Fibre Yield and Quality of Fibrous Jute (Corchorus capsularis L.) Plants Grown Under Two Different Soils of China. Plants 2020, 9, 404. [CrossRef]

63. Saleem, M.H.; Ali, S.; Rehman, M.; Rizwan, M.; Kamran, M.; Mohamed, I.A.; Bamagoos, A.A.; Alharby, H.F.; Hakeem, K.R.; Liu, L. Individual and combined application of EDTA and citric acid assisted phytoextraction of copper using jute (Corchorus capsularis L.) seedlings. Environ. Technol. Innov. 2020, 19, 100895. [CrossRef]

64. Anwer, S.; Ashraf, M.Y.; Hussain, M.; Ashraf, M.; Jamil, A. Citric acid mediated phytoextraction of cadmium by maize (Zea mays L.). Pak. J. Bot. 2012, 44, 1831-1836.

65. Tanwir, K.; Akram, M.S.; Masood, S.; Chaudhary, H.J.; Lindberg, S.; Javed, M.T. Cadmium-induced rhizospheric pH dynamics modulated nutrient acquisition and physiological attributes of maize (Zea mays L.). Environ. Sci. Pollut. Res. 2015, 22, 9193-9203. [CrossRef] [PubMed]

66. Keller, C.; Rizwan, M.; Davidian, J.-C.; Pokrovsky, O.; Bovet, N.; Chaurand, P.; Meunier, J.-D. Effect of silicon on wheat seedlings (Triticum turgidum L.) grown in hydroponics and exposed to 0 to $30 \mu \mathrm{M} \mathrm{Cu}$. Planta 2015, 241, 847-860. [CrossRef] [PubMed]

67. Adrees, M.; Ali, S.; Rizwan, M.; Zia-ur-Rehman, M.; Ibrahim, M.; Abbas, F.; Farid, M.; Qayyum, M.F.; Irshad, M.K. Mechanisms of silicon-mediated alleviation of heavy metal toxicity in plants: A review. Ecotoxicol. Environ. Saf. 2015, 119, 186-197. [CrossRef]

68. Tang, H.; Liu, Y.; Gong, X.; Zeng, G.; Zheng, B.; Wang, D.; Sun, Z.; Zhou, L.; Zeng, X. Effects of selenium and silicon on enhancing antioxidative capacity in ramie (Boehmeria nivea (L.) Gaud.) under cadmium stress. Environ. Sci. Pollut. Res. 2015, 22, 9999-10008. [CrossRef]

69. Collin, B.; Doelsch, E.; Keller, C.; Panfili, F.; Meunier, J.-D. Effects of silicon and copper on bamboo grown hydroponically. Environ. Sci. Pollut. Res. 2013, 20, 6482-6495. [CrossRef]

70. Alyemeni, M.N.; Ahanger, M.A.; Wijaya, L.; Alam, P.; Bhardwaj, R.; Ahmad, P. Selenium mitigates cadmium-induced oxidative stress in tomato (Solanum lycopersicum L.) plants by modulating chlorophyll fluorescence, osmolyte accumulation, and antioxidant system. Protoplasma 2018, 255, 459-469. [CrossRef] 